\title{
BBT improves glucose homeostasis by ameliorating $\beta$-cell dysfunction in type 2 diabetic mice
}

\author{
Xin-gang Yao", Xin Xu*, Gai-hong Wang, Min Lei, Ling-ling Quan', Yan-hua Cheng², \\ Ping Wan', Jin-pei Zhou'², Jing Chen, Li-hong Hu and Xu Shen \\ Key Laboratory of Receptor Research, Shanghai Institute of Materia Medica, Chinese Academy of Sciences, \\ 555 Zuchongzhi Road, Shanghai 201203, China \\ ${ }^{1}$ College of Life and Environmental Sciences, Shanghai Normal University, 100 Guilin Road, Shanghai 200234, China \\ ${ }^{2}$ Department of Pharmacology, China Pharmaceutical University, 24 Tongjiaxiang, Nanjing 210009, China \\ ${ }^{*}(\mathrm{X}-\mathrm{g}$ Yao and X Xu contributed equally to this work)
}

Correspondence should be addressed to X Shen, L-h Hu or J Chen Emails xshen@simm.ac.cn; Ihhu@simm.ac.cn; jingchen@simm.ac.cn

\begin{abstract}
Impaired glucose-stimulated insulin secretion (GSIS) and increasing $\beta$-cell death are two typical dysfunctions of pancreatic $\beta$-cells in individuals that are destined to develop type 2 diabetes, and improvement of $\beta$-cell function through GSIS enhancement and/or inhibition of $\beta$-cell death is a promising strategy for anti-diabetic therapy. In this study, we discovered that the small molecule, $\mathrm{N}$-(2-benzoylphenyl)-5-bromo-2-thiophenecarboxamide (BBT), was effective in both potentiating GSIS and protecting $\beta$-cells from cytokine- or streptozotocin (STZ)-induced cell death. Results of further studies revealed that CAMP/PKA and long-lasting (L-type) voltage-dependent $\mathrm{Ca}^{2+}$ channel/CaMK2 pathways were involved in the action of BBT against GSIS, and that the CAMP/PKA pathway was essential for the protective action of BBT on $\beta$-cells. An assay using the model of type 2 diabetic mice induced by high-fat diet combined with STZ (STZ/HFD) demonstrated that BBT administration efficiently restored $\beta$-cell functions as indicated by the increased plasma insulin level and decrease in the $\beta$-cell loss induced by STZ/HFD. Moreover, the results indicated that BBT treatment decreased fasting blood glucose and $\mathrm{HbA} 1 \mathrm{c}$ and improved oral glucose tolerance further highlighting the potential of BBT in anti-hyperglycemia research.
\end{abstract}

\section{Key Words}

- $\beta$-cell dysfunction

- glucose-stimulated insulin secretion (GSIS)

- $\beta$-cell death

- glucose homeostasis

\section{Introduction}

Type 2 diabetes is a global epidemic chronic disease that is characterized by resistance in responding to the normal actions of insulin and progressive dysfunction of pancreatic $\beta$-cells in secreting sufficient amounts of insulin for normal metabolic demand (Leahy 1990). Pathologically, dysfunction of $\beta$-cells is characterized by the loss of glucose-stimulated insulin secretion (GSIS) and $\beta$-cell death that leads to a reduction in insulin content and $\beta$-cell mass. Thus, amelioration of $\beta$-cell dysfunction by activating GSIS or/and blocking $\beta$-cell death has been determined to be one of the promising approaches in delaying or preventing the onset of type 2 diabetes (Rhodes 2005, Prentki \& Nolan 2006, Seino et al. 2011, Rachdi et al. 2014).

The mechanism of GSIS is well elucidated. It is suggested that glucose is transported into $\beta$-cells by GLUT2 and metabolized through the tricarboxylic acid cycle and mitochondrial electron transport chain, thus inducing the increase in the ratio of ATP:ADP (Brownlee 2005). The elevated ATP:ADP ratio stimulates the closure

Published by Bioscientifica Ltd. 
of $\mathrm{K}_{\mathrm{ATP}}$ channels, leading to membrane depolarization. Long-lasting (L-type) voltage-dependent $\mathrm{Ca}^{2+}$ channel (L-VDCC) is then opened and the extracellular $\mathrm{Ca}^{2+}$ enters into cells, finally triggering insulin release (Suzuki et al. 1999). In addition, extracellular $\mathrm{Ca}^{2+}$ influx through L-VDCC also induces $\mathrm{Ca}^{2+}$ release from endoplasmic reticulum. Elevation of intracellular $\mathrm{Ca}^{2+}$ activates $\mathrm{Ca}^{2+} /$ calmodulin to phosphorylate diverse substrates involved in insulin secretion, including $\mathrm{Ca}^{2+} / \mathrm{CaM}$ protein kinase 2 (CaMK2), $\mathrm{Ca}^{2+} / \mathrm{CaMK}$ kinase (CaMKK), protein kinase C (PKC), and ERK1/2 (Easom 1999). Besides intracellular $\mathrm{Ca}^{2+}$, intracellular cAMP also plays an important role in insulin secretion (Cognard et al. 2013). Elevation of intracellular cAMP directly activates cAMPdependent PKA, thereby potentiating GSIS (Kaihara et al. 2013). In the clinical treatment of type 2 diabetic patients, sulfonylureas are the most widely used drugs to enhance insulin secretion, although they may cause hypoglycemia because of their long duration and glucose-independent effect on insulin secretion (Meece 2007, Seino et al. 2010). Recently, GLP1 analogs and DPP4 inhibitors, such as exendin-4 and vildagliptin, have been demonstrated to have glucose-dependent effects in stimulating GSIS (Ahren 2008, Chia \& Egan 2008, Doupis \& Veves 2008, Girgis \& Champion 2011).

Apart from GSIS dysfunction, reduced $\beta$-cell mass is also strongly associated with the development of type 2 diabetes (Butler et al. 2003). Chronic hyperglycemia induces high levels of reactive oxygen species and interleukin 1B (IL1B), causing $\beta$-cell death (Maedler et al. 2002, Kajimoto \& Kaneto 2004), and abnormal accumulation of lipids in $\beta$ cells by hyperlipidemia can also induce $\beta$-cell death (Wrede et al. 2002). It has been reported that the cAMP-mediated cytoprotection against apoptosis involves PKA, MAPK, and PI3K pathways (Webster \& Anwer 1998), and GLP1 demonstrates anti-apoptotic activity by activating these pathways in pancreatic cells (Hui et al. 2003). In addition, rosiglitazone (Han et al. 2008), GLP1, and its analogues (Li et al. 2005) could also inhibit the glucolipotoxicity-induced $\beta$-cell death.

Therefore, based on the above analyses, it is believed that a reagent able to both activate GSIS and protect against $\beta$-cell death may demonstrate potent anti-diabetic potential. Accordingly, we performed the screening against the Specs commercial compound library and the small molecule, $\mathrm{N}$-(2-benzoylphenyl)-5-bromo-2-thiophenecarboxamide (BBT, Fig. 1A), was identified. BBT could not only potentiate GSIS but also protect $\beta$-cells from streptozotocin (STZ)- or cytokine-induced $\beta$-cell death, and effectively ameliorate glucose homeostasis in STZ/ high-fat diet (HFD)-induced type 2 diabetic mice. Further study of the mechanism revealed that cAMP/PKA pathways are responsible for functions of BBT in GSIS stimulation and $\beta$-cell protection. Our current work has highlighted the potential of BBT in the treatment of hyperglycemia.

\section{Materials and methods}

\section{Materials and reagents}

GF109203X (GFX), H89, MDL-12,330A, EGTA, repaglinide, STO-609, KN93, and nifedipine were purchased from Sigma-Aldrich. BBT was obtained from a commercial compound library (Specs, Zoetermeer, the Netherlands).

\section{Cell culture}

INS-832/13 cells were kindly provided by Professor Yong Liu (Institute for Nutritional Sciences, SIBS, Chinese Academy of Sciences) and grown in RPMI 1640 medium supplemented with $10 \%$ FBS, $5.6 \mathrm{mM}$ glucose, $25 \mathrm{mM}$ HEPES, $2 \mathrm{mM}$ L-glutamine, $50 \mathrm{mM} \beta$-mercaptoethanol, $100 \mathrm{U} / \mathrm{ml}$ penicillin, and $100 \mathrm{mg} / \mathrm{ml}$ streptomycin at $37^{\circ} \mathrm{C}$ in a humidified atmosphere containing 95\% air and $5 \% \mathrm{CO}_{2}$. Culture medium, FBS, and supplements were purchased from Invitrogen. Pancreatic islets from C57/BL6 mice ( 6 weeks) were isolated using the liberase digestion method (Yao et al. 2013). Briefly, pancreas was digested with liberase enzyme, and the digest was fractionated by gradient centrifugation preformed in $13,21,23$, and $25 \%$ ficoll. The islet fractions were then harvested between 13 and $21 \%$ gradients into Hank's balanced salt solution (Sigma), and finally individual mouse islets were handpicked with a pipette under a microscope. The islets were cultured in RPMI 1640 supplemented with 10\% FBS at $37^{\circ} \mathrm{C}$ in an environment of $5 \% \mathrm{CO}_{2}$ overnight.

\section{3-(4,5-Dimethylthiazol-2-yl)-2,5-diphenyltetrazolium bromide and 5-Bromo-2'-deoxyuridine assays}

INS-832/13 cells were seeded at a density of $2 \times 10^{4}$ cells/well in 48-well plates and allowed to attach overnight, they were then treated with BBT and STZ $(0.4 \mathrm{mM})$ or cytokines $(10 \mathrm{ng} / \mathrm{ml}$ tumor necrosis factor alpha (TNF $\alpha$ ) and $5 \mathrm{ng} / \mathrm{ml} \mathrm{IL1B)}$ for $24 \mathrm{~h}$, and incubated with $0.5 \mathrm{mg} / \mathrm{ml}$ of 3-(4,5-dimethylthiazol-2-yl)-2,5-diphenyltetrazolium bromide (MTT) for $4 \mathrm{~h}$ to test cell viability. The formazan crystals formed were dissolved in DMSO and analyzed using a Benchmark Plus microplate reader at $570 \mathrm{~nm}$

Published by Bioscientifica Ltd 
A<smiles>O=C(Nc1ccccc1C(=O)c1ccccc1)c1ccc(Br)s1</smiles>

D

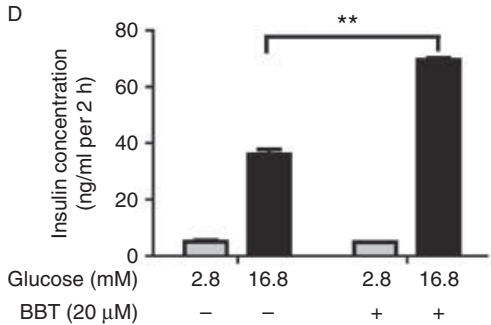

G

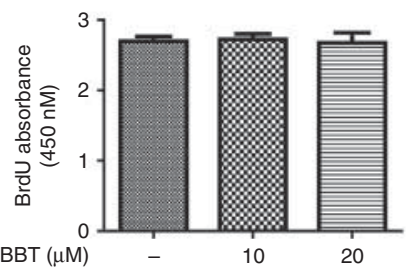

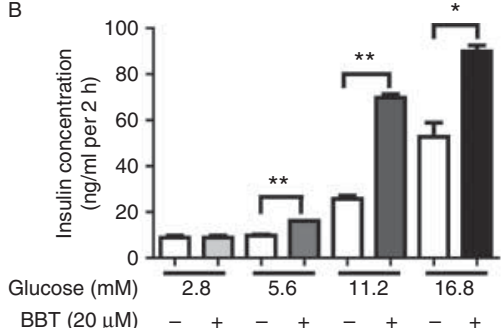

E
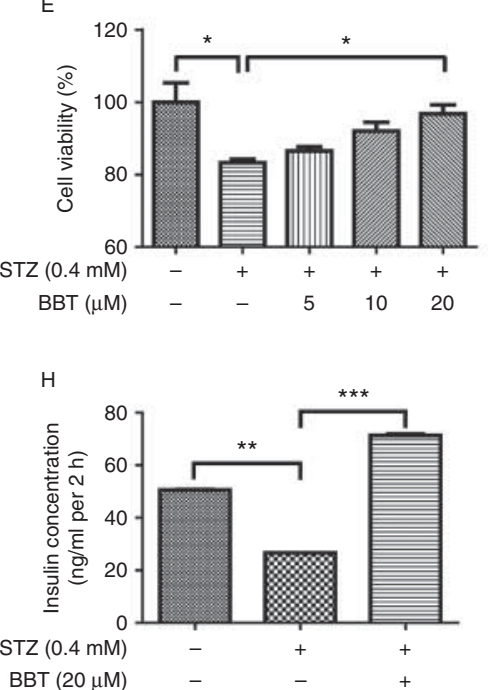

C

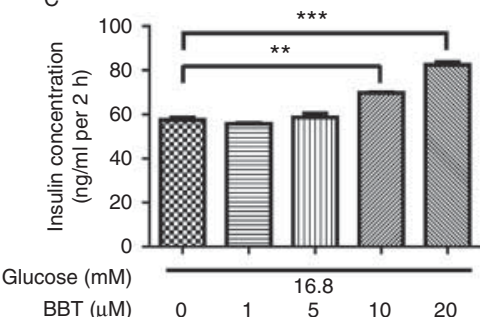

$\mathrm{F}$
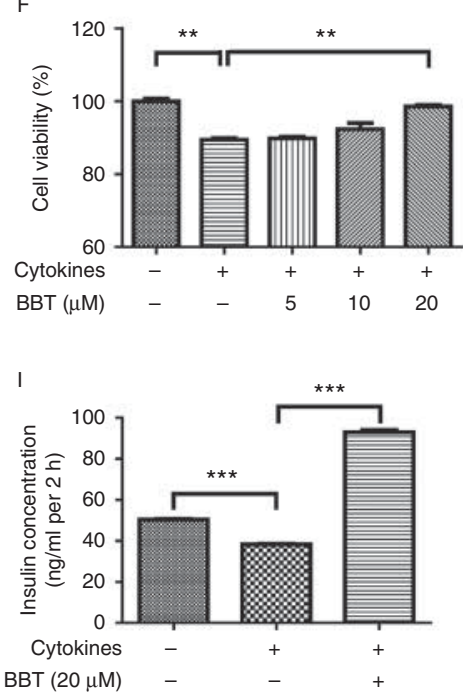

\section{Figure 1}

BBT-potentiated GSIS and protected against $\beta$-cell death. (A) Chemical structure of BBT. (B) After 2-h incubation with glucose-free KRB buffer, INS-832/13 cells were stimulated with $2.8,5.6,11.2$, or $16.8 \mathrm{mM}$ glucose, respectively, in the presence or absence of BBT $(20 \mu \mathrm{M})$ for $2 \mathrm{~h}$, and insulin secretion was determined by ELISA assay. (C) After $2 \mathrm{~h}$ incubation with glucose-free KRB buffer, INS-832/13 cells were stimulated with $16.8 \mathrm{mM}$ glucose in the presence of BBT $(1,5,10$, and $20 \mu \mathrm{M})$ for $2 \mathrm{~h}$, and then insulin secretion was determined. (D) After 2-h incubation with glucose-free KRB buffer, primary islets were stimulated with 2.8 or $16.8 \mathrm{mM}$ glucose in the presence of BBT $(20 \mu \mathrm{M})$ for $2 \mathrm{~h}$, and then insulin secretion was determined. (E) STZ (0.4 mM) or (F) cytokines (10 ng/ml TNF $\alpha$ and $5 \mathrm{ng} / \mathrm{ml}$ IL1B) were

(Bio-Rad). 5-Bromo-2'-deoxyuridine (BrdU) assay was used to analyze the incorporation of BrdU during DNA synthesis following the manufacturer's protocols (Cell Signaling Technology, Danvers, MA, USA).

\section{Intracellular $\mathrm{Ca}^{2+}$ measurement}

INS-832/13 cells were plated into 96-well plates at a density of $1 \times 10^{4}$ cell/well and incubated overnight. After $1 \mathrm{~h}$ starvation in glucose-free KRB buffer, cells were loaded with $80 \mu \mathrm{l}$ of the $\mathrm{Ca}^{2+}$ dye (Fluo-4 AM) and then incubated at $37^{\circ} \mathrm{C}$ for $40 \mathrm{~min}$. Intracellular $\mathrm{Ca}^{2+}$ influx was analyzed by FlexStation II384 (Molecular Devices, Sunnyvale, CA, USA) with an excitation wavelength of used to induced INS-832/13 cell death, BBT $(5,10$, and $20 \mu \mathrm{M})$ co-incubated with STZ or cytokines for $24 \mathrm{~h}$, and cell viability was determined by MTT assay. (G) INS-832/13 cells were incubated with BBT $(10$ and $20 \mu \mathrm{M})$ for $24 \mathrm{~h}$, and then cell proliferation was detected by 5-Bromo-2'-deoxyuridine (BrdU) assay. INS-832/13 cells were incubated in the glucose-free KRB buffer containing (H) STZ or (I) cytokines ( $10 \mathrm{ng} / \mathrm{ml} \mathrm{TNF} \alpha$ and $5 \mathrm{ng} / \mathrm{ml} \mathrm{IL1B}$ ) in the presence of the indicated compounds for $2 \mathrm{~h}$, and then stimulated with $16.8 \mathrm{mM}$ glucose KRB buffer in the presence of BBT $(20 \mu \mathrm{M})$ for $2 \mathrm{~h}$, and insulin secretion was determined. All data were obtained from three independent experiments and are presented as means \pm s.E.M. $\left({ }^{*} P<0.05\right.$, $* * P<0.01$, and $* * * P<0.001)$.

$485 \mathrm{~nm}$ and an emission wavelength of $525 \mathrm{~nm}$. After the baseline fluorescence signal was measured for the first $16 \mathrm{~s}$ at $2.8 \mathrm{mM}$ glucose, the test compound prepared as a $3 \times$ stock in Hank's balanced salt solution buffer and $16.8 \mathrm{mM}$ glucose was added to the plate through an automated pipette (50 $\mu \mathrm{l} /$ well). The relative fluorescence signals were measured at $1.6 \mathrm{~s}$ intervals for $60-120 \mathrm{~s}$.

\section{Luciferase activity assay}

Luciferase report plasmid (CRE-Luc) and Renilla luciferase plasmid were kindly provided by Professor Yong Liu (Institute for Nutritional Sciences, SIBS, Chinese Academy of Sciences). HEK293T or INS-832/13 cells were transfected

Published by Bioscientifica Ltd 
with cAMP-responsive luciferase reporter plasmid (CRE-Luc) plus Renilla luciferase plasmid for $5 \mathrm{~h}$, and then incubated with the indicated concentrations of compounds for another $18 \mathrm{~h}$. Finally, the cells were lysed and luciferase activities measured using the Dual Luciferase Assay System Kit (Promega). The results were presented as the fold-change of activation compared with the untreated cells after normalization using Renilla luciferase values. Each experiment was repeated at least three replicates.

\section{GSIS assay}

INS-832/13 cells were seeded in 24-well plates and incubated in $5 \% \mathrm{CO}_{2}$ for $48 \mathrm{~h}$. Briefly, cells were preincubated with Krebs-Ringer bicarbonate HEPES buffer (KRB buffer: $115 \mathrm{mM} \mathrm{NaCl}, 5 \mathrm{mM} \mathrm{KCl}, 1 \mathrm{mM} \mathrm{MgCl}_{2}$, $24 \mathrm{mM} \mathrm{NaHCO}, 2.5 \mathrm{mM} \mathrm{CaCl} 2$, and $10 \mathrm{mM}$ HEPES) supplemented with $0.5 \%$ BSA for $2 \mathrm{~h}$, followed by incubation in KRB buffer containing 2.8, 5.6, 11.2, or $16.8 \mathrm{mM}$ glucose with indicated compounds for $2 \mathrm{~h}$. The supernatant of the cells was collected for the determination of insulin secretion. Insulin concentration was measured using the Rat/Mouse Insulin ELISA Kit (Millipore, Billerica, MA, USA).

\section{Western blotting analysis}

MABs against ERK1/2 and p-ERK1/2 were purchased from Cell Signaling Technology. For western blot analysis, cell lysate was separated by SDS-PAGE and transferred to PVDF membrane (Amersham Biosciences). After incubation with corresponding antibodies overnight, the membranes were visualized using the Dura detection system (Thermo Scientific, Waltham, MA, USA). For immunohistochemistry analysis, the pancreas was removed and fixed in $10 \%$ paraformaldehyde solution. The tissues were subsequently embedded in paraffin and cut into sections with a thickness of $5 \mu \mathrm{m}$ using a microtome. The sections were incubated with insulin antibody for $1 \mathrm{~h}$ and then biotinylated rabbit anti-goat IgG for $30 \mathrm{~min}$ at room temperature, and labeled using a modified avidin-biotin complex immunoperoxidase staining procedure. Positive staining was visualized using DAB peroxidase substrate solution for 5-10 $\mathrm{min}$, and tissues were counterstained with hematoxylin.

\section{Intracellular cAMP assay}

Intracellular cAMP was detected by using the ELISA Assay Kit (R\&D, Minneapolis, MN, USA). INS-832/13 cells were washed three times in cold PBS $(137 \mathrm{mM} \mathrm{NaCl}, 2.7 \mathrm{mM}$
$\mathrm{KCl}, 10 \mathrm{mM} \mathrm{Na}_{2} \mathrm{HPO}_{4}, 2 \mathrm{mM} \mathrm{KH}_{2} \mathrm{PO}_{4}$, and $\mathrm{pH}$ 7.2), and then resuspended in lysis buffer to a concentration of $10^{7}$ cells $/ \mathrm{ml}$. The cells were frozen at $-20^{\circ} \mathrm{C}$ and thawed at room temperature for three cycles, and then centrifuged at $600 \mathrm{~g}$ for $10 \mathrm{~min}$ at $4{ }^{\circ} \mathrm{C}$. The supernatant was analyzed according to the manufacture's protocol. cAMP content was calculated by the standard curve.

\section{Type 2 diabetic animal model and BBT administration}

All animals were received humane care, and the animalrelated protocols were approved by the Institutional Animal Care and Use Committees at Shanghai Institute of Materia Medica, CAS. The STZ/HFD-induced type 2 diabetic mice model was constructed mainly based on the published approaches (Wang et al. 2000, Wu et al. 2005, Arulmozhi et al. 2008). Six-week-old male mice were fed with HFD (consisting of $58 \%$ fat, $17 \%$ carbohydrate, and $25 \%$ protein) for 4 weeks and then administered STZ at $25 \mathrm{mg} / \mathrm{kg}$ in $0.1 \mathrm{M}$ citrate-buffered saline ( $\mathrm{pH} 4.5$ ) by intraperitoneal (i.p.) injection after $8 \mathrm{~h}$ fasting for 5 consecutive days. Fasting plasma glucose was measured in STZ-injected mice after 3 days to select the diabetic mice for use. Diabetic mice were subdivided into two groups: the control group $(n=9)$ and the BBT treatment group ( $50 \mathrm{mg} / \mathrm{kg}$ per day) $(n=9)$. BBT was administrated by i.p. injection daily for 4 weeks. Fasting plasma glucose was measured weekly. At the termination of the study, mice were killed and tissues were analyzed. In addition, the mice administrated HFD or normal chow diet were used to evaluate the effects of BBT on $\beta$-cell mass. Six-week-old male mice were fed with HFD similarly to the HFD/STZ model mice or with normal chow for 6 weeks and then i.p. injected daily with BBT for 4 weeks.

Oral glucose tolerance test The oral glucose tolerance test (OGTT) was carried out on the STZ/HFD-induced diabetic mice fasted overnight. $1.5 \mathrm{~g} / \mathrm{kg}$ glucose was administered orally with a gavage needle. Glucose levels were measured from tail blood at $0,15,30,60,90$, and 120 min using the ACCU-CHEK Active blood sugar system (Roche). Meanwhile, the insulin release during OGTT was also measured, blood samples were obtained from tail veins and serum insulin concentration was determined using the ELISA Kit (Millipore).

Insulin tolerance test The insulin tolerance test (ITT) was carried out on the STZ/HFD-induced diabetic mice fasted overnight. $1 \mathrm{U} / \mathrm{kg}$ insulin was administered by peritoneal injection. Glucose levels were measured from

Published by Bioscientifica Ltd 
tail blood at $0,15,30,60,90$, and $120 \mathrm{~min}$ using the ACCU-CHEK Active blood sugar system (Roche).

\section{Statistical analysis}

Data are shown as mean \pm s.E.m. Student's $t$-test was performed for comparison of two groups and one-way ANOVA for comparison of more than two groups using GraphPad Prism 5.0 Software (La Jolla, CA, USA) with values of $P<0.05$ being statistically significant. Significant differences are indicated by ${ }^{*} P<0.05,{ }^{*} P<0.01$, and ${ }^{* * *} P<0.001$.

\section{Results}

\section{BBT improved pancreatic $\beta$-cell dysfunction}

INS-832/13 cells which present high response to changes in glucose concentration (Hohmeier et al. 2000) were used to screen the active compounds from the Specs commercial library with features of potentiating GSIS and protecting $\beta$-cells. After screening approximately 8000 compounds, BBT was finally determined to have the most potent dual-function among 12 candidates.

BBT-potentiated GSIS As indicated in Fig. 1B, BBTstimulated insulin secretion in a glucose-dependent manner. The results shown in Fig. 1C further confirmed that BBT dose-dependently potentiated GSIS in the cells with a high concentration of glucose $(16.8 \mathrm{mM})$. In addition, we also isolated the primary islets and detected the effects of BBT on GSIS. As indicated in Fig. 1D, BBT enhanced GSIS in primary islets. These results indicated that BBT affected GSIS per se.

BBT protected against $\beta$-cell death In the investigation of BBT protection against $\beta$-cell death, the compound was assayed for its activity in protecting against the STZor cytokine-induced INS-832/13 cell death. As shown in Fig. 1E and F, treatment with STZ $(0.4 \mathrm{mM})$ or cytokines $(10 \mathrm{ng} / \mathrm{ml} \mathrm{TNF} \alpha$ and $5 \mathrm{ng} / \mathrm{ml}$ IL1B) induced $\beta$-cell death, and BBT effectively reversed this effect in a dose-dependent manner. In addition, BBT itself had no effects on $\beta$-cell proliferation according to the BrdU assay (Fig. 1G).

BBT improved the STZ- or cytokine-induced GSIS defect In addition, by considering that STZ or cytokines can induce $\beta$-cell secretory defects (Delaney et al. 1995, Andersson et al. 2001), we also examined whether BBT was effective in improving $\beta$-cell secretory defects induced by treatment with STZ or cytokines. As shown in Fig. $1 \mathrm{H}$ and I, BBT could expectedly reverse the STZ- or cytokineinduced GSIS defect.

Accordingly, all the above results indicated that BBT improved pancreatic $\beta$-cell dysfunction by both potentiating GSIS and protecting $\beta$-cells from the STZ- or cytokines-induced cell death.

\section{ERK1/2 regulation is involved in the BBT-potentiated GSIS}

Next, we tried to investigate the underlying mechanism of BBT in the improvement of pancreatic $\beta$-cell dysfunction. It has been reported that ERK phosphorylation, as one of the MAPK signaling pathways, functions potently in cell survival and apoptosis (Xia et al. 1995), and that the ERK pathway is linked closely to $\beta$-cell apoptosis and insulin secretion (Wijesekara et al. 2010, Yeo et al. 2012). In this study, based on the effects of BBT in both potentiating GSIS and protecting $\beta$-cells, we thus wondered whether ERK regulation was also involved in such BBT-induced events. Accordingly, we carried out related assays in INS832/13 cells.

BBT-stimulated ERK1/2 phosphorylation In the investigation of the effect of glucose on the BBT-activated ERK1/2 phosphorylation, the cells were incubated for $2 \mathrm{~h}$ in glucose-free KRB buffer, followed by incubation with various concentrations of glucose in the presence of BBT $(20 \mu \mathrm{M})$ for $2 \mathrm{~h}$. As indicated in Fig. 2A, $2.8 \mathrm{mM}$ glucose failed to activate ERK1/2 phosphorylation, and BBT had no effects on ERK1/2 activation with $2.8 \mathrm{mM}$ glucose, while BBT induced a sustained increase in ERK1/2 phosphorylation in the presence of $5.6,11.2$, and $16.8 \mathrm{mM}$ glucose. In addition, as shown in Fig. 2B, BBT, as expected, stimulated ERK1/2 phosphorylation in the cells with $16.8 \mathrm{mM}$ glucose in a dose-dependent manner.

Therefore, these results indicated that BBT stimulated ERK1/2 phosphorylation in both glucose- and dosedependent manners, which is consistent with its regulation of GSIS (Fig. 1B and C).

The ERK1/2 pathway is involved in the BBT-potentiated GSIS To further examine the association of ERK1/2 regulation with the BBT-potentiated GSIS, we carried out assays in the cells, in which U0126 (a specific MEK/ERK1/2 inhibitor (Duncia et al. 1998)) was used. As shown in Fig. 2C and D, U0126 treatment with the cells in $16.8 \mathrm{mM}$ glucose dose-dependently decreased the BBT-potentiated ERK1/2 phosphorylation, and

Published by Bioscientifica Ltd 
A

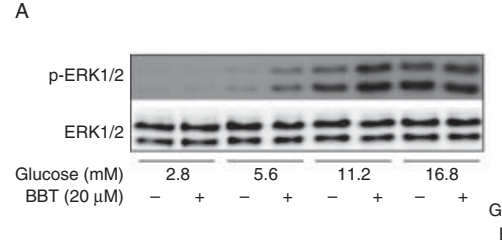

B

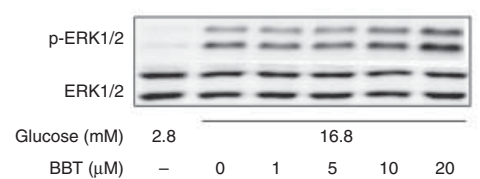

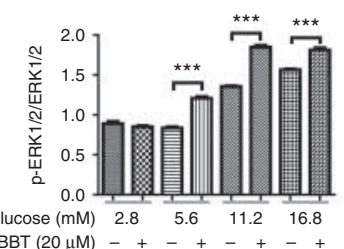

BBT $(20 \mu \mathrm{MM})-+\quad+\quad+\quad+\quad+\quad-$

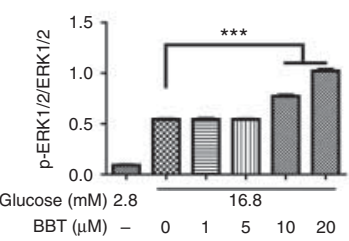

C
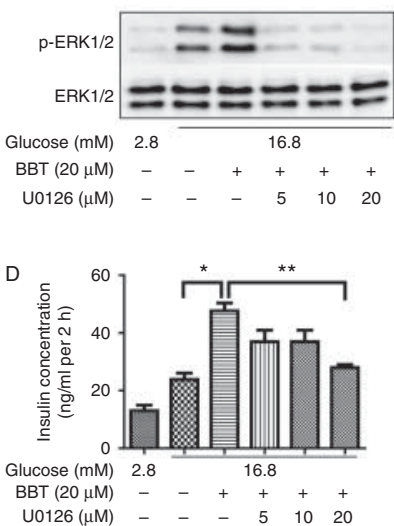

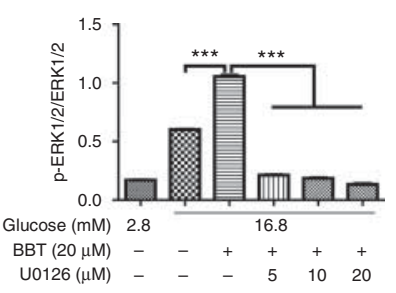

\section{Figure 2}

BBT-potentiated glucose-induced ERK1/2 activation. (A) After 2-h incubation with glucose-free KRB buffer, INS-832/13 cells were stimulated with $2.8,5.6,11.2$, or $16.8 \mathrm{mM}$ glucose in the presence or absence of BBT $(20 \mu \mathrm{M})$ for $2 \mathrm{~h}$, and the cell lysate was analyzed by western blotting using p-ERK1/2 and ERK1/2 antibodies. (B) After 2-h incubation with glucose-free KRB buffer, INS-832/13 cells were stimulated with $16.8 \mathrm{mM}$ glucose in the presence of BBT $(1,5,10$, and $20 \mu \mathrm{M})$ for $2 \mathrm{~h}$, and the cell lysate was analyzed by western blotting. (C) INS-832/13 cells were incubated with

high concentration of U0126 at $20 \mu \mathrm{M}$ significantly decreased the BBT-potentiated GSIS. These results thereby indicated that the ERK1/2 pathway is involved in the BBT-potentiated GSIS.

\section{CAMP/PKA signaling is involved in the BBT-potentiated GSIS and ERK1/2 phosphorylation}

Given that ERK1/2 has been determined to be involved in the BBT-potentiated GSIS and that the cAMP/PKA pathway plays potent roles in ERK1/2 phosphorylation and insulin secretion (Renstrom et al. 1997), we next inspected the potential association of the CAMP/PKA pathway with the BBT-potentiated GSIS in INS-832/13 cells.

As demonstrated in Fig. 3A, BBT $(20 \mu \mathrm{M})$ increased intracellular cAMP with $16.8 \mathrm{mM}$ glucose. Accordingly, we determined whether cAMP was essential for the BBT-potentiated GSIS. In the assay, MDL-12,330A (an adenylyl cyclase (AC)-specific inhibitor (Seifert et al. 2012)) was used. As shown in Fig. 3B and C, MDL$12,330 \mathrm{~A}(20 \mu \mathrm{M})$ treatment of cells in $16.8 \mathrm{mM}$ glucose strongly decreased the BBT-potentiated GSIS and ERK1/2 phosphorylation. These results thus indicated that the cAMP pathway was involved in the BBT-potentiated GSIS and ERK1/2 activation.

Generally, the effects of cAMP in regulated exocytosis are considered to be mediated by the activation of cAMPdependent PKA, a main cAMP target (Renstrom et al.
U0126 $(5,10$, and $20 \mu \mathrm{M})$ in glucose-free KRB buffer for $2 \mathrm{~h}$, and then incubated for $2 \mathrm{~h}$ in 2.8 or $16.8 \mathrm{mM}$ glucose in the presence of BBT ( $20 \mu \mathrm{M})$ with $\operatorname{U} 0126(5,10$, and $20 \mu \mathrm{M})$. The cell lysate was analyzed by western blotting. (D) The supernatant of the cells in (C) was collected and insulin concentration was determined by ELISA assay. All data were obtained from three independent experiments and are presented as means \pm S.E.M. $(* P<0.05, * * P<0.01$, and $* * * P<0.001)$.

1997). Thus, we performed an assay for inspecting the potential involvement of PKA regulation in the BBT-potentiated GSIS and ERK1/2 phosphorylation, where INS-832/13 cells were pre-incubated with H89 (a specific PKA inhibitor (Chijiwa et al. 1990)) in glucosefree KRB buffer for $2 \mathrm{~h}$, followed by stimulation with $16.8 \mathrm{mM}$ glucose in the presence of BBT. As shown in Fig. 3D and E, H89 treatment potently decreased the BBT-potentiated GSIS and ERK1/2 phosphorylation.

Therefore, all the results indicated that the cAMP/PKA pathway is involved in the BBT-potentiated GSIS and ERK1/2 phosphorylation.

\section{L-VDCC/CaMK2 is involved in the BBT-potentiated GSIS}

$\mathrm{Ca}^{2+}$ is essential for the BBT-potentiated GSIS As reported, besides the cAMP/PKA pathway, $\mathrm{Ca}^{2+}$-influxrelated signaling also functions potently in insulin secretion (Rustenbeck et al. 1997). Accordingly, we carried out the relevant assays to examine the potential effect of BBT on intracellular $\mathrm{Ca}^{2+}$ levels. Intracellular $\mathrm{Ca}^{2+}$ measurement results are shown in Fig. 4A. BBT obviously enhanced the high-glucose-(16.8 mM)-induced intracellular $\mathrm{Ca}^{2+}$ level. To further clarify whether such an enhanced intracellular $\mathrm{Ca}^{2+}$ level was associated with extracellular $\mathrm{Ca}^{2+}$ influx or endoplasmic reticulum $\mathrm{Ca}^{2+}$ release, EGTA (a chelating agent of the extracellular $\mathrm{Ca}^{2+}$ (Gomez et al. 2002)) and thapsigargin (an inhibitor of

Published by Bioscientifica Ltd. 
A

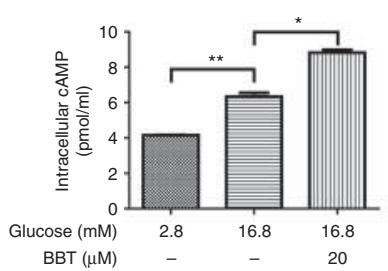

B

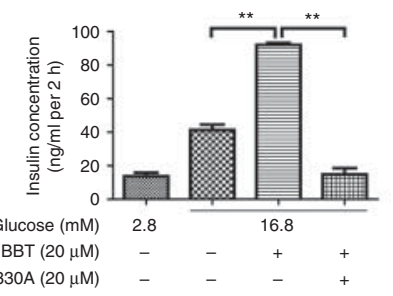

C

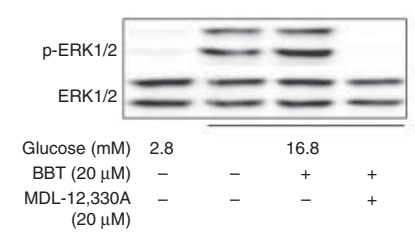

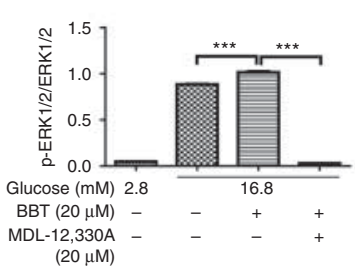

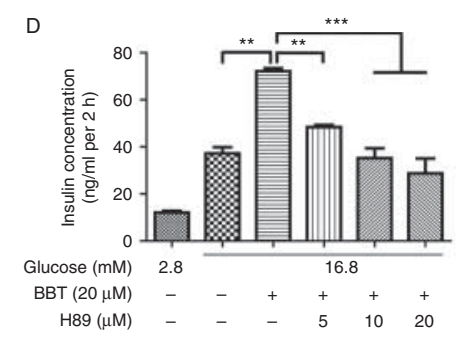

$E$

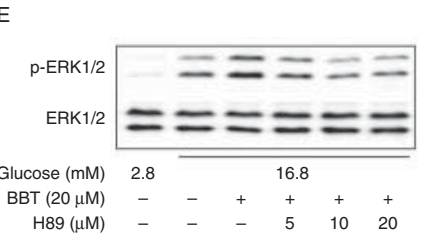

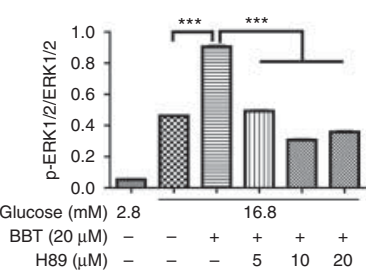

Figure 3

CAMP/PKA pathway participated in the BBT-potentiated GSIS. (A) INS-832/13 cells were pre-incubated in glucose-free KRB buffer for $2 \mathrm{~h}$, and then stimulated with 2.8 or $16.8 \mathrm{mM}$ glucose in the presence or absence of BBT $(20 \mu \mathrm{M})$ for $2 \mathrm{~h}$, and the cells were collected for determining intracellular CAMP levels. (B) INS-832/13 cells were pre-incubated in glucose-free KRB buffer with MDL-12,330A ( $20 \mu \mathrm{M})$ for $2 \mathrm{~h}$, and then stimulated with 2.8 or $16.8 \mathrm{mM}$ glucose for $2 \mathrm{~h}$ in the presence of BBT $(20 \mu \mathrm{M})$ or BBT $(20 \mu \mathrm{M})$ with MDL-12,330A $(20 \mu \mathrm{M})$, the insulin concentration was determined by ELISA

endoplasmic reticulum $\mathrm{Ca}^{2+}$ release (Lytton et al. 1991)) were applied. As indicated in Fig. 4B, EGTA $(0.5 \mathrm{mM})$ treatment totally inhibited the BBT-stimulated insulin secretion, but BBT could reverse the thapsigargin-(1 or $10 \mu \mathrm{M})$-treatment-stimulated decrease in insulin secretion. The results indicated that $\mathrm{Ca}^{2+}$ was essential for the BBTpotentiated GSIS and that endoplasmic reticulum $\mathrm{Ca}^{2+}$ release was not the main factor for the BBT-potentiated GSIS.

Extracellular $\mathrm{Ca}^{2+}$ influx is mainly responsible for the BBTpotentiated GSIS As demonstrated previously, endoplasmic reticulum $\mathrm{Ca}^{2+}$ release was not the main factor in the BBT-potentiated GSIS. Therefore, we investigated the relationship between extracellular $\mathrm{Ca}^{2+}$ influx and BBTpotentiated GSIS. A specific L-VDCC blocker (nifedipine) was applied (Quevedo et al. 1998). As shown in Fig. 4C, nifedipine dose-dependently reversed the BBT-potentiated GSIS. This result thus indicated that L-VDCC was involved in the BBT-potentiated GSIS.

The $\mathrm{K}_{\text {ATP }}$ channel is not involved in BBT-potentiated GSIS Given that the $\mathrm{K}_{\mathrm{ATP}}$ channel plays an important role in the glucose-induced $\mathrm{Ca}^{2+}$ influx (Shibasaki et al. 2004), we investigated the potential association of the $K_{\text {ATP }}$ channel with the BBT-potentiated GSIS. As shown in Fig. 4D, repaglinide (a specific $\mathrm{K}_{\mathrm{ATP}}$ channel blocker (Stephan et al. 2006)) alone significantly increased insulin secretion in the

assay. (C) The cell lysate from (B) was analyzed by western blotting. (D) INS$832 / 13$ cells were incubated in glucose-free KRB buffer with or without $\mathrm{H} 89$ $(5,10$, and $20 \mu \mathrm{M})$ for $2 \mathrm{~h}$, and stimulated with 2.8 or $16.8 \mathrm{mM}$ glucose for $2 \mathrm{~h}$ in the presence of BBT $(20 \mu \mathrm{M})$ or BBT $(20 \mu \mathrm{M})$ with $\mathrm{H} 89(5,10$, and $20 \mu \mathrm{M})$. Insulin concentration was determined by ELISA assay. (E) The cell lysate in (D) was analyzed by western blotting. All data were obtained from three independent experiments and are presented as means \pm S.E.M. $(* P<0.05$, $* * P<0.01$, and $* * * P<0.001)$.

cells with $16.8 \mathrm{mM}$ glucose. In view of the fact that repaglinide at $10 \mathrm{nM}$ could inhibit the $\mathrm{K}_{\mathrm{ATP}}$ channel by almost 95\% in pancreatic cells (Stephan et al. 2006), high concentrations of repaglinide at 1 or $10 \mu \mathrm{M}$ (Fig. 4D) were thus suggested to be obviously enough to totally blockade the $\mathrm{K}_{\mathrm{ATP}}$ channel as indicated by the result that the repaglinide-stimulated insulin secretion reached a peak at 1 and $10 \mu \mathrm{M}$ (Fig. 4D). Therefore, the finding that BBT could still enhance insulin secretion in the presence of repaglinide implied that BBT was not a direct blocker of the $\mathrm{K}_{\mathrm{ATP}}$ channel.

Next, diazoxide (an opener of the $\mathrm{K}_{\mathrm{ATP}}$ channel (Ritzel et al. 2004)) was thus used in an attempt to elucidate the effect of BBT downstream or upstream of the $\mathrm{K}_{\mathrm{ATP}}$ channel. As also shown in Fig. 4D, although diazoxide decreased the BBT-potentiated GSIS, BBT could still reverse the effect of diazoxide on GSIS, this result combined with above information from the experiments using the $\mathrm{K}_{\mathrm{ATP}}$ channel blocker indicated that the $\mathrm{K}_{\mathrm{ATP}}$ channel might not be involved in BBT-potentiated GSIS. This suggestion could be also supported by the assay examining the involvement of ERK1/2, where BBT obviously stimulated the diazoxide/ repaglinide-regulated ERK1/2 phosphorylation (Fig. 4E), similar to the cases for diazoxide and repaglinide in the regulation of GSIS.

L-VDCC/CaMK2 pathway is involved in the BBTpotentiated GSIS Given that L-VDCC is involved in

Published by Bioscientifica Ltd. 


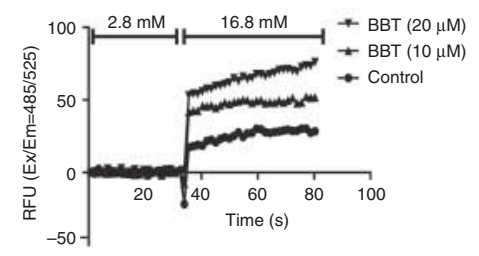

B

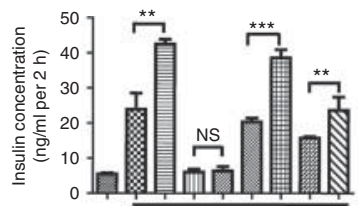

Glucose $(\mathrm{mM}) 2.8$

BGTA $(20.5 \mathrm{mM})$

Thapsigargin $(1 \mu \mathrm{M})$

Thapsigargin $(10 \mu \mathrm{M})$
C

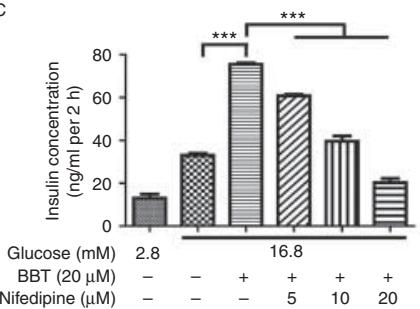

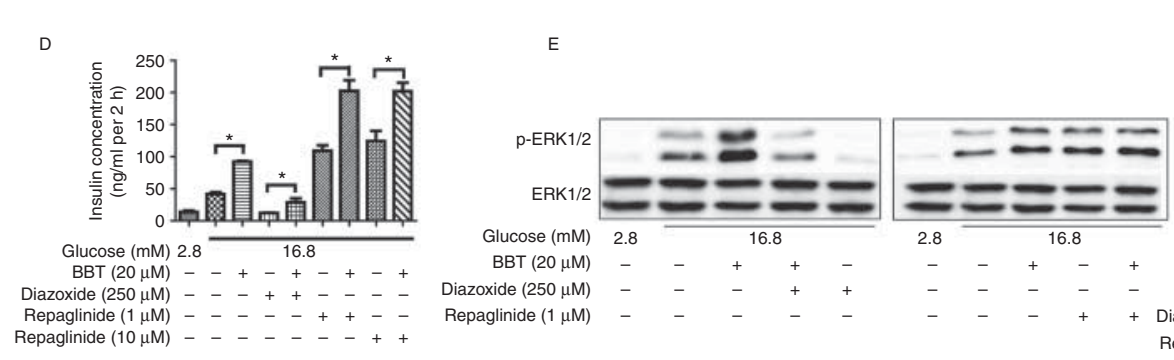

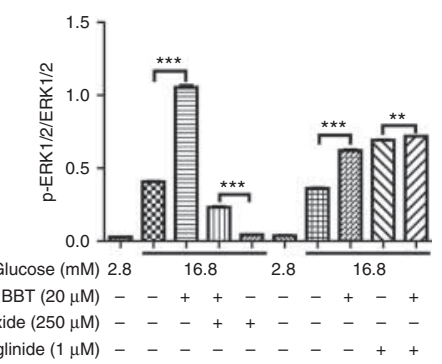

$\mathrm{F}$

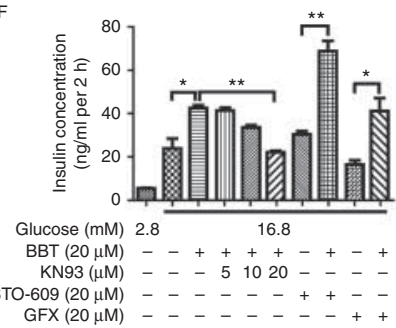

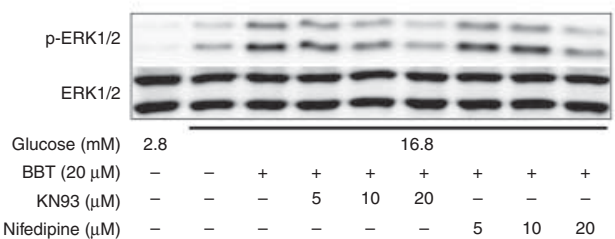

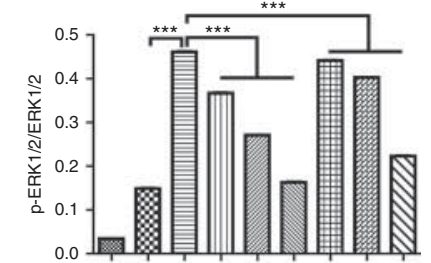

Glucose (mM) 2.8

KNT $(20 \mu \mathrm{M})-+++++++$ Nifedipine $(\mu \mathrm{M})$ - $\quad$ - $\quad-\quad-\quad-\quad-\quad 5 \quad 1020$
Figure 4

L-VDCC/CaMK2 activation is involved in the BBT-potentiated GSIS.

(A) Intracellular $\mathrm{Ca}^{2+}$ level in INS-832/13 cells was monitored using Fluo-4 AM fluorescence dye. The cells were incubated with $2.8 \mathrm{mM}$ glucose for $16 \mathrm{~s}$, followed by stimulation with $16.8 \mathrm{mM}$ glucose in the presence of BBT (10 and $20 \mu \mathrm{M})$, and fluorescent signals were detected. (B) INS-832/13 cells were incubated in glucose-free KRB buffer with or without EGTA $(0.5 \mathrm{mM})$ and thapsigargin $(1 \mu \mathrm{M})$ for $2 \mathrm{~h}$, and then incubated in 2.8 or $16.8 \mathrm{mM}$ glucose in the presence or absence of BBT $(20 \mu \mathrm{M})$, EGTA $(0.5 \mathrm{mM}), \mathrm{BBT}$ with EGTA, thapsigargin $(1 \mu \mathrm{M})$, BBT with thapsigargin $(1 \mu \mathrm{M})$, thapsigargin $(10 \mu \mathrm{M})$ or BBT with thapsigargin $(10 \mu \mathrm{M})$ for $2 \mathrm{~h}$, and insulin concentrations were determined by ELISA assay. (C) INS-832/13 cells were pre-incubated in glucose-free KRB buffer with or without nifedipine $(5,10$, and $20 \mu \mathrm{M}$ ) for $2 \mathrm{~h}$, and then stimulated with 2.8 or $16.8 \mathrm{mM}$ glucose KRB buffer for $2 \mathrm{~h}$ in the presence of BBT $(20 \mu \mathrm{M})$ or BBT with nifedipine $(5,10$, and $20 \mu \mathrm{M}$ ), for $2 \mathrm{~h}$, insulin concentrations were determined by ELISA assay.

the BBT-potentiated GSIS, the potential action of BBT against the L-VDCC downstream $\mathrm{Ca}^{2+}$-dependent protein kinases, including PKC, CaMK2, and CaMKK, were investigated in INS-832/13 cells.

In the assay, the cells were separately incubated with GFX (a PKC inhibitor (Yokota et al. 2003)), KN93 (a CaMK2 inhibitor (Sumi et al. 1991)), or STO-609 (a CaMKK inhibitor (Tokumitsu et al. 2003)) for $2 \mathrm{~h}$ in glucose-free KRB buffer, followed by stimulation with $16.8 \mathrm{mM}$ glucose in the presence or absence of BBT for another $2 \mathrm{~h}$. As shown in Fig. 4F, only KN93 dose-dependently blocked the
(D) INS-832/13 cells were pre-incubated in glucose-free KRB buffer with or without diazoxide $(250 \mu \mathrm{M})$ and repaglinide $(1$ and $10 \mu \mathrm{M})$ for $2 \mathrm{~h}$, and then stimulated with 2.8 or $16.8 \mathrm{mM}$ glucose for $2 \mathrm{~h}$ in the presence of BBT $(20 \mu \mathrm{M})$, diazoxide $(250 \mu \mathrm{M})$, BBT with diazoxide $(250 \mu \mathrm{M})$, repaglinide (1 and $10 \mu \mathrm{M}$ ) or BBT with repaglinide (1 and $10 \mu \mathrm{M})$, insulin concentrations were determined by ELISA assay. (E) The cell lysate from (D) was analyzed by western blotting. (F) INS-832/13 cells were pre-incubated in glucose-free KRB buffer with or without STO-609 $(20 \mu \mathrm{M}), \operatorname{GFX}(20 \mu \mathrm{M})$, or $\operatorname{KN} 93(5,10$, and $20 \mu \mathrm{M}$ ) for $2 \mathrm{~h}$, and then stimulated with 2.8 or $16.8 \mathrm{mM}$ glucose KRB buffer for $2 \mathrm{~h}$ in the presence of BBT $(20 \mu \mathrm{M})$, STO-609 $(20 \mu \mathrm{M})$, BBT with STO-609 $(20 \mu \mathrm{M})$, GFX $(20 \mu \mathrm{M})$, BBT with GFX $(20 \mu \mathrm{M})$, or BBT with KN93 $(5,10$, and $20 \mu \mathrm{M})$ for $2 \mathrm{~h}$, insulin concentration were determined by ELISA assay. (G) The cell lysate from (B) and (F) was analyzed by western blotting. All data were obtained from three independent experiments and are presented as means \pm s.E.M. $\left({ }^{*} P<0.05, * * P<0.01\right.$, and $\left.* * * P<0.001\right)$.

BBT-potentiated GSIS, implying that CaMK2 activation might contribute to the BBT-potentiated GSIS. Moreover, INS-832/13 cells pretreated with STO-609 or GFX displayed greater increases in insulin secretion in the presence of $\mathrm{BBT}$, this might be the result of the fact that extracellular the $\mathrm{Ca}^{2+}$ influx induced by BBT might activate its downstream kinases including PKC, CaMK2, and CaMKK, and inhibition of PKC or CaMKK activation could better focus the extracellular $\mathrm{Ca}^{2+}$ influx induced by BBT into the activation of CaMK2 and increase the insulin secretion. In addition, the results indicating that both 
nifedipine and KN93 dose-dependently decreased the BBTpotentiated ERK1/2 phosphorylation further confirmed that L-VDCC and its downstream kinase CaMK2 were involved in the BBT-potentiated GSIS (Fig. 4G). Therefore, all results indicated that the L-VDCC/CaMK2 pathway is involved in the BBT-potentiated GSIS.

\section{CAMP/PKA as an upstream pathway of L-VDCC/CaMK2 is responsible for the $\mathrm{BBT}$-enhanced $\mathrm{Ca}^{2+}$ influx}

As BBT has been determined to activate intracellular cAMP and $\mathrm{Ca}^{2+}$ influx, we next investigated the association of
cAMP with the BBT-enhanced intracellular $\mathrm{Ca}^{2+}$ in INS$832 / 13$ cells. In the assay, the cells were incubated with MDL-12,330A $(20 \mu \mathrm{M})$ or H89 $(20 \mu \mathrm{M})$ in glucose-free KRB buffer for $2 \mathrm{~h}$, and then stimulated with $16.8 \mathrm{mM}$ glucose in the presence or absence of BBT $(20 \mu \mathrm{M})$. As shown in Fig. 5A, either MDL-12,330A or H89 decreased the enhancement of the intracellular level of $\mathrm{Ca}^{2+}$ induced by BBT, which indicated that cAMP/PKA was involved in the BBT-activated $\mathrm{Ca}^{2+}$ influx. It is noted that the effect of BBT in enhancing the high-glucose-(16.8 mM)-induced intracellular $\mathrm{Ca}^{2+}$ level is not so obvious compared with the result shown in Fig. 4A, this might be caused by the

A

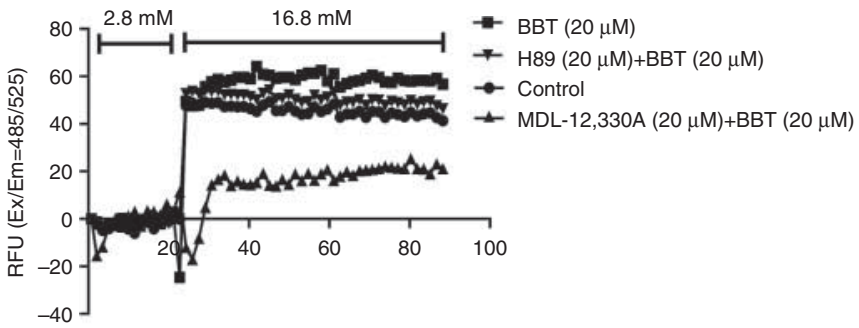

B

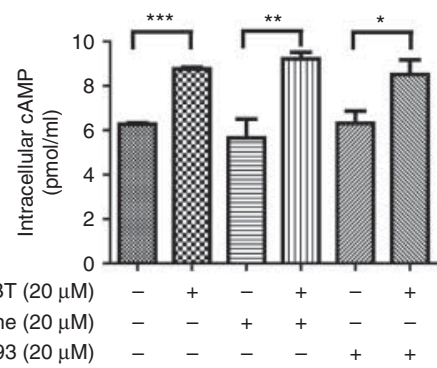

D

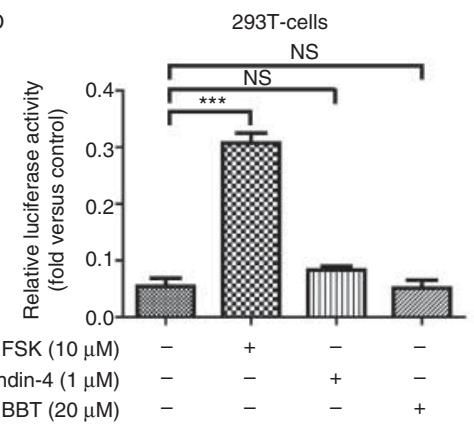

Figure 5

CAMP/PKA as an upstream pathway of L-VDCC/CaMK2 is responsible for the BBT-enhanced $\mathrm{Ca}^{2+}$ influx. (A) Intracellular $\mathrm{Ca}^{2+}$ levels were monitored using Fluo-4 AM fluorescence dye in INS-832/13 cells. The cells were pre-incubated in glucose-free KRB buffer for $2 \mathrm{~h}$ and then stimulated with $2.8 \mathrm{mM}$ glucose for $16 \mathrm{~s}$, followed by stimulation with $16.8 \mathrm{mM}$ glucose in the presence of BBT $(20 \mu \mathrm{M})$, BBT with $\mathrm{H} 89(20 \mu \mathrm{M})$, or BBT with MDL$12,330 \mathrm{~A}(20 \mu \mathrm{M})$, the fluorescent signal was detected. (B) INS-832/13 cells were incubated in glucose-free KRB buffer with or without nifedipine $(20 \mu \mathrm{M})$ or KN93 $(20 \mu \mathrm{M})$ for $2 \mathrm{~h}$, and stimulated with $16.8 \mathrm{mM}$ glucose for $2 \mathrm{~h}$ with BBT $(20 \mu \mathrm{M})$, nifedipine $(20 \mu \mathrm{M})$, BBT with nifedipine $(20 \mu \mathrm{M})$, KN93 (c) 2015 Society for Endocrinology Printed in Great Britain
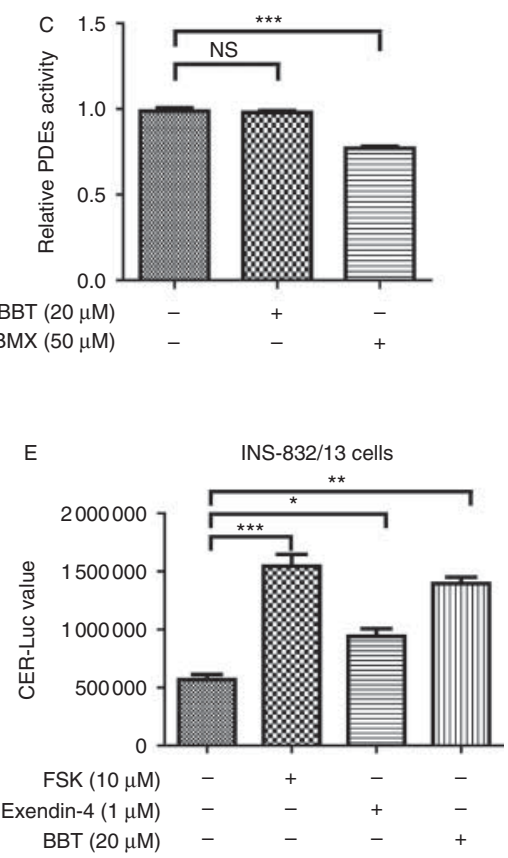

$(20 \mu \mathrm{M})$, or BBT $(20 \mu \mathrm{M})$ with $\mathrm{KN} 93(20 \mu \mathrm{M})$, the cells were collected to determine intracellular CAMP levels. (C) PDEs activity was determined by enzyme activity assay, and then the effects of BBT $(20 \mu \mathrm{M})$ and 3-isobutyl-1-methylxanthine (IBMX) $(50 \mu \mathrm{M})$ were detected. (D) 293T cells or (E) INS-832/13 cells were transfected with CAMP-responsive luciferase reporter plasmid (CRE-Luc, $300 \mathrm{ng} /$ well) in 24-well plates and then the cells were treated with FSK $(10 \mu \mathrm{M})$, exendin- $4(1 \mu \mathrm{M})$, or BBT $(20 \mu \mathrm{M})$ for $18 \mathrm{~h}$, and luciferase activity was determined. All data were obtained from three independent experiments and are presented as means \pm S.E.M. $(* P<0.05$, $* * P<0.01$, and $* * * P<0.001)$. 
change in absolute live-cell numbers in different batches of experiments. Next, the role of L-VDCC or CaMK2 activity in the increase in intracellular cAMP due to BBT was examined. As shown in Fig. 5B, neither nifedipine nor KN93 affected the enhancement of intracellular cAMP by $\mathrm{BBT}$. Therefore, these results indicated that cAMP/PKA as an upstream pathway of L-VDCC/CaMK2 is responsible for the increase in $\mathrm{Ca}^{2+}$ influx induced by BBT. Given that cAMP is regulated by PDEs, AC, and GPCRs (Szkudelski 2001), we also performed the relevant assays in an attempt to determine the potential targets of BBT. We found that IBMX as an inhibitor of PDEs decreased the activity of PDEs and that BBT had no effects on the activity of PDEs, which indicated that BBT was not an inhibitor of PDEs (Fig. 5C). Considering the similarity of AC catalytic
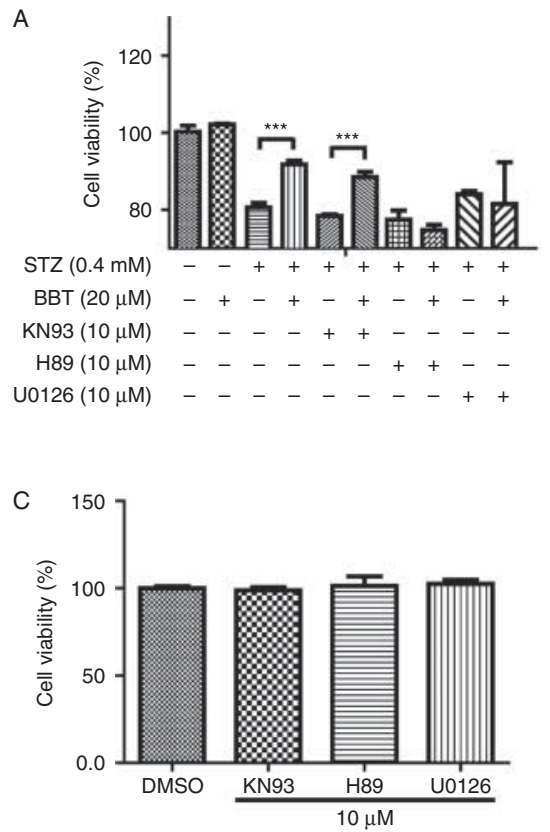

E

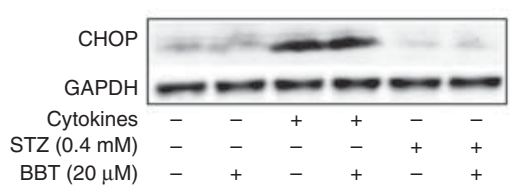

Figure 6

The CAMP/PKA pathway is involved in BBT-induced $\beta$-cell protection. INS-832/13 cells were incubated with (A) STZ $(0.4 \mathrm{mM})$ or $(B)$ cytokines (10 $\mathrm{ng} / \mathrm{ml} \mathrm{TNF} \alpha$ and $5 \mathrm{ng} / \mathrm{ml} \mathrm{IL1B}$ ) in the presence of the indicated compounds for $24 \mathrm{~h}$, and then cell viability was evaluated by MTT assay. (C) INS-832/13 cells were incubated with the kinase inhibitors (KN93, H89, or U0126), and then cell viability was evaluated by MTT assay. (D) INS-832/13 domains to each other and that activator of AC could activate all types of AC, such as forskolin (FSK; Szkudelski 2001), cAMP-responsive luciferase reporter plasmid (CRELuc) was next used to study whether BBT targeted AC or GPCRs. In the assay, CRE-Luc plasmid was transfected into 293T-cells (Fig. 5D) or INS-832/13 cells (Fig. 5E). It was found that FSK $(10 \mu \mathrm{M})$ enhanced the luciferase activity in both $293 \mathrm{~T}$ and INS-832/13 cells, while BBT $(20 \mu \mathrm{M})$ only enhanced the luciferase activity in INS-832/13 cells similarly to the GLP1 receptor agonist, exendin-4, which indicated that BBT enhanced intracellular cAMP through GPCR on $\beta$-cells. On the basis of its effects on cAMP, we speculated that BBT might act as a GPCR agonist coupled to Gs. Furthermore, we investigated whether BBT could active GLP1 receptor, GPR35 and GPR55, but,
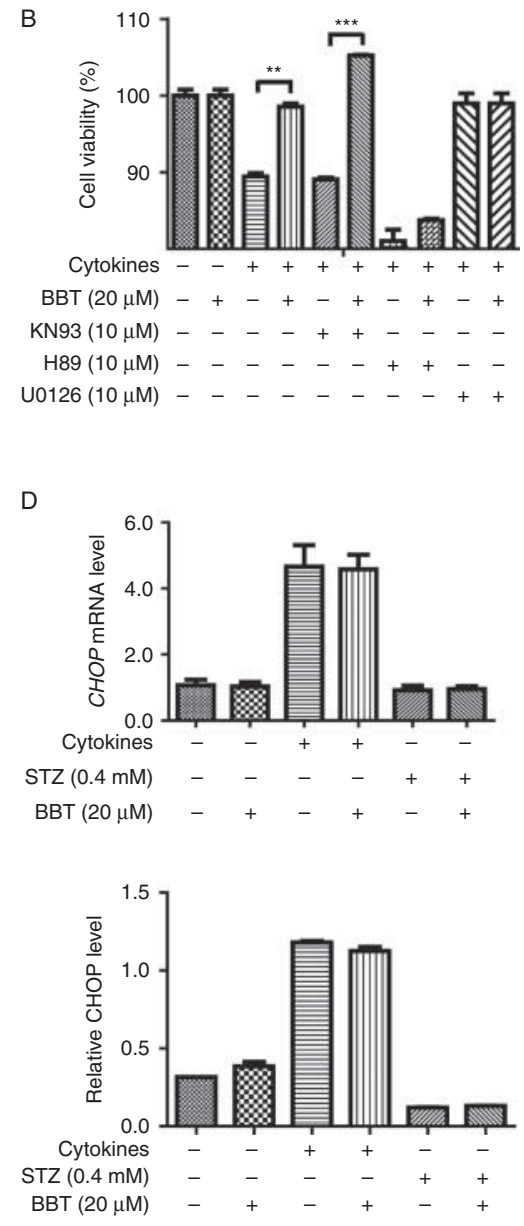

cells were incubated with STZ $(0.4 \mathrm{mM})$ or cytokines $(10 \mathrm{ng} / \mathrm{ml} \mathrm{TNF} \alpha$ and $5 \mathrm{ng} / \mathrm{ml} \mathrm{IL1B})$ in the presence or absence of BBT $(20 \mu \mathrm{M})$ for $24 \mathrm{~h}$, and then mRNA level of $C H O P$ was determined. (E) Protein level of $\mathrm{CHOP}$ was determined by western blotting. All data were obtained from three independent experiments and are presented as means \pm S.E.M. $(* * P<0.01$, and $* * * P<0.001)$.

Published by Bioscientifica Ltd 


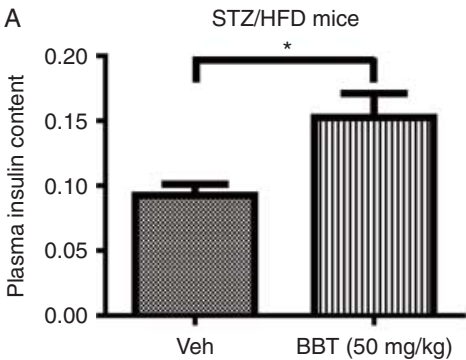

C

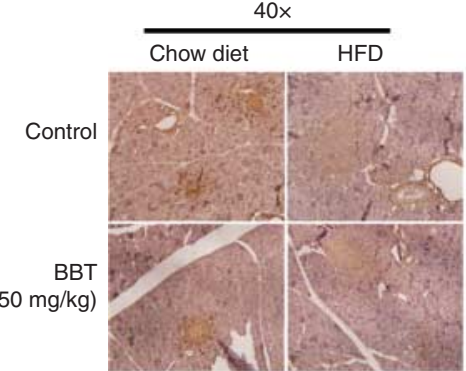

D

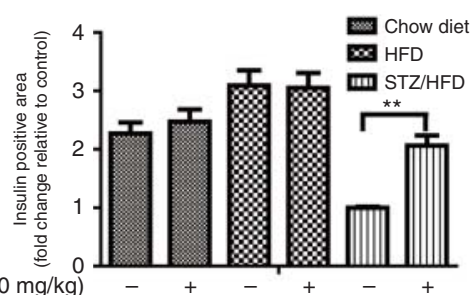

B

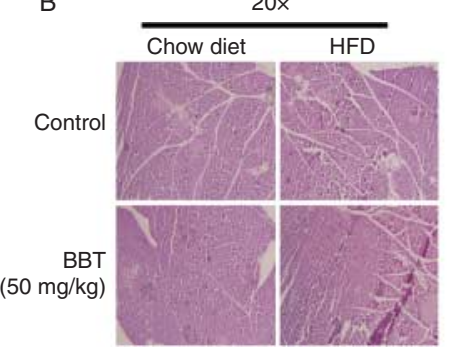

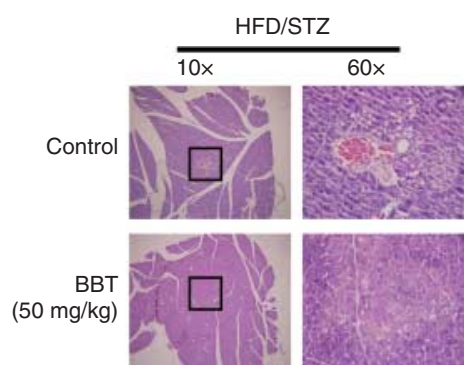

HFD/STZ

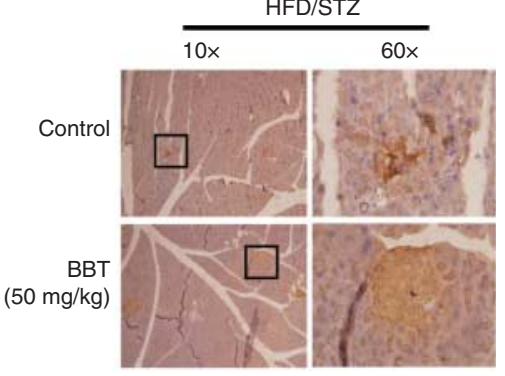

E $\quad$ - Control

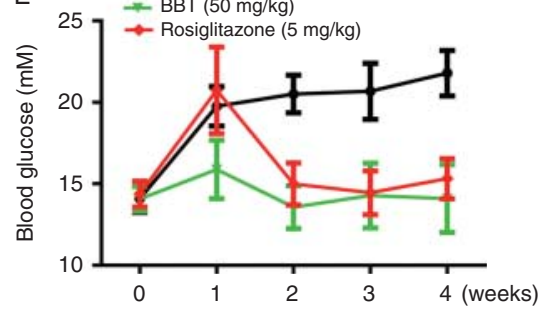

OGTT

G

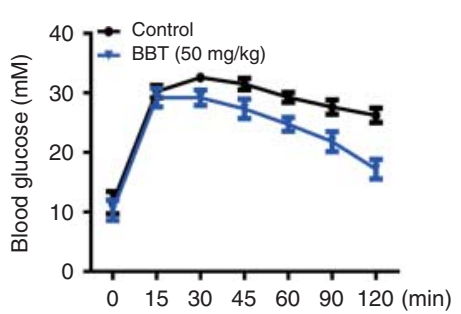

$\mathrm{H}$

OGTT
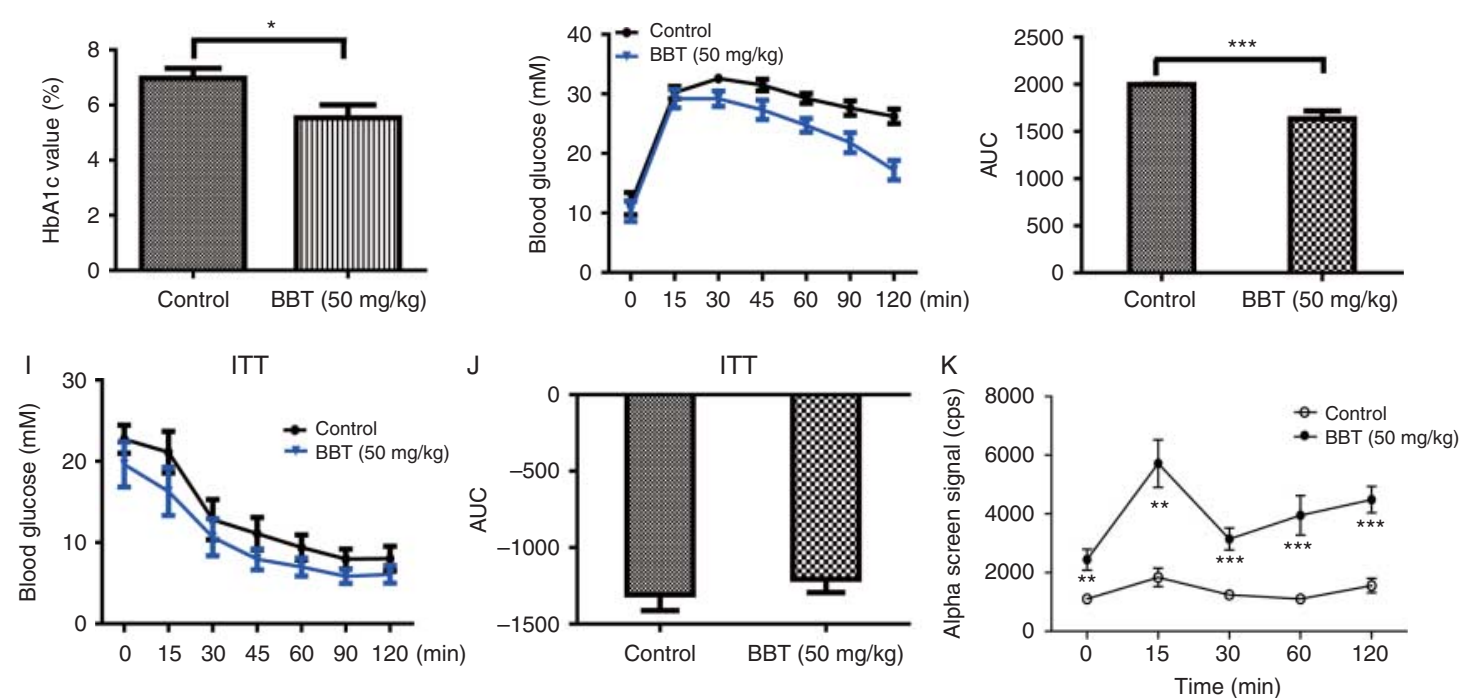

\section{Figure 7}

BBT ameliorated glucose homeostasis in the STZ/HFD-induced type 2 diabetic mice. (A) Fasting serum insulin levels were detected in STZ/HFDinduced type 2 diabetic mice after BBT ( $50 \mathrm{mg} / \mathrm{kg}$ per day) treatment $(n=9)$. (B) Morphology (HE staining) and (C) insulin immunohistochemistry of pancreatic $\beta$-cells in chow-diet-fed, HFD-fed, or HFD-fed/STZ-induced mice were examined. (D) Quantification of insulin-positive islets in (C). (E) Fasting serum glucose level was detected in mice after BBT $(50 \mathrm{mg} / \mathrm{kg}$ per
(C) 2015 Society for Endocrinology Printed in Great Britain day) or rosiglitazone $(5 \mathrm{mg} / \mathrm{kg})$ treatment $(n=9)$. (F) Serum HbA1c level in mice after BBT (50 mg/kg per day) treatment was determined. (G) OGTT was performed in mice after BBT ( $50 \mathrm{mg} / \mathrm{kg}$ per day) treatment $(n=9)$. (H) AUC result for OGTT in (G). (I) ITT was performed in mice after BBT $(50 \mathrm{mg} / \mathrm{kg}$ per day) treatment $(n=9)$. (J) AUC result for ITT in (I). (K) Serum insulin concentration was determined during OGTT. All data are presented as means \pm s.E.M. $\left({ }^{*} P<0.05, * * P<0.01\right.$, and $\left.* * * P<0.001\right)$. 
disappointingly, could not directly activate the above GPCRs responsible for insulin secretion (data not shown). Further research is ongoing.

\section{The CAMP/PKA pathway is involved in the protection of BBT against $\beta$-cell}

Given that cAMP/PKA, L-VDCC/CaMK2, and ERK1/2 pathways have been determined to be involved in the BBT-potentiated GSIS, we next inspected the potential mechanism involving BBT in the protection of $\beta$-cells. In the assay, INS-832/13 cells were incubated with KN93 (H89 or U0126) and STZ or cytokines in the presence or absence of BBT, and $\beta$-cell viability was then detected. As shown in Fig. 6A and B, in either of the two models with STZ- or cytokine-induced $\beta$-cell death, KN93 treatment did not affect the protective action of BBT on $\beta$-cells, but H89 and U0126 efficiently deprived the effect of BBT on $\beta$-cell protection. Notably, BBT itself has no effects on cell viability and none of KN93, H89, and U0126 exhibited any effects on cell viability by themselves (Fig. 6C). Therefore, the influences of these kinase inhibitors on BBT thereby implied that cAMP/PKA and ERK1/2 not the L-VDCC/CaMK2 pathway was involved in the protective effect of BBT against $\beta$-cell death.

Given the possibility that upregulation of ERK may suppress CHOP expression thereby protecting $\beta$-cells against apoptosis, we also carried out the relevant assays. As demonstrated in Fig. 6D and E, BBT had no effects on the mRNA or protein level of CHOP, which indicated that $\mathrm{CHOP}$ was not involved in BBT events.

Therefore, all results indicated that the cAMP/PKA/ ERK1/2 pathway is involved in the protective action of BBT on $\beta$-cells.

\section{BBT ameliorated glucose homeostasis in STZ/HFD-induced type 2 diabetic mice}

BBT improved $\beta$-cell dysfunction in vivo Considering that BBT was effective in both stimulating insulin secretion and protecting pancreatic $\beta$-cells, we further performed the in vivo assay against HFD/STZ-induced type 2 diabetic mice to investigate the potential of BBT in the improvement of glucose homeostasis. Given that results presented in a published report (Wang et al. 2000) have revealed the almost similar plasma insulin content of the mice treated with or without STZ/HFD, in this study we emphatically studied the effect of BBT on the serum insulin content of the STZ/HFD-induced type 2 diabetic mice. As indicated in Fig. 7A, BBT treatment increased serum insulin levels, which was consistent with the in vitro results (Fig. 1C). Moreover, the protective effect of BBT against pancreatic islets death was also evaluated by investigation of the morphology and the insulin-positive islets in STZ/HFDinduced type 2 diabetic mice. As demonstrated in Fig. 7B, C and $\mathrm{D}$, compared with the disrupted islets of the control groups in the mice, BBT treatment effectively reduced the STZ/HFD-induced disruption of islets (Fig. 7B), and more insulin-positive islets were clearly preserved after treatment of the mice with BBT (Fig. 7C and D). In addition, we also found BBT could neither change islet morphology (Fig. 7B) nor increase the insulin-positive $\beta$-cell area in normal chow-diet-fed and HFD-fed mice (Fig. 7C and D). This result thereby indicated that BBT primarily inhibited the reduction in $\beta$-cell mass instead of $\beta$-cell mass increment.

BBT ameliorated glucose homeostasis in STZ/HFD-induced type 2 diabetic mice Next, we explored the potential effect of BBT on glucose homeostasis in STZ/HFD-induced type 2 diabetic mice. The type 2 diabetic model in our study was also at first confirmed using rosiglitazone, the generally accepted reagent for type 2 diabetes but not type 1 diabetes (Gastaldelli 2011). The finding that rosiglitazone $(5 \mathrm{mg} / \mathrm{kg})$ significantly decreased the fasting glucose level of STZ/HFD-induced diabetic mice (Fig. 7E) clearly confirmed the type 2 diabetic features of the model. As shown in Fig. 7E and F, chronic administration of BBT for 4 weeks efficiently reduced the fasting serum glucose and HbA1c levels in the mice. In addition, the results of the OGTT assay indicated that BBT treatment was effective in improving the glucose tolerance in HFD/STZ-induced type 2 diabetic mice (Fig. $7 \mathrm{G}$ and $\mathrm{H}$ ), and that BBT had no effects on the ITT assay (Fig. 7I and J). Furthermore, BBT treatment effectively increased the serum insulin concentration during the OGTT (Fig. 7K), which thus strengthened support for the insulinotrophic effect of BBT in vivo.

\section{Discussion}

Type 2 diabetes is a chronic metabolic disease, which has brought much burden to societies (Zimmet et al. 2001). Although the underlying pathological basis of type 2 diabetes is not clear, insulin resistance and $\beta$-cell dysfunction contribute much to this heterogeneous disease (Gastaldelli 2011). Recently, amelioration of $\beta$-cell dysfunction by activation of GSIS and/or prevention of $\beta$-cell death have been determined to be promising approaches in delaying or preventing the onset of type 2 diabetes (Rhodes 2005, Prentki \& Nolan 2006, Seino et al. 2011, Rachdi et al. 2014). In this work, we found that the

Published by Bioscientifica Ltd. 
thiophenecarboxamide derivative BBT was effective in both enhancing GSIS and alleviating $\beta$-cell death, and the results of the in vivo assay further demonstrated its capabilities in the improvement of glucose homeostasis in type 2 diabetic mice. These results thus highlighted the potential of BBT in anti-diabetic research.

ERK1/2 has been implicated in many cellular events, including proliferation, differentiation, survival, and secretion (Volmat \& Pouyssegur 2001). In $\beta$-cells, the glucose-activated ERK1/2 regulated insulin gene transcription and insulin secretion (Benes et al. 1999). Although the role of ERK1/2 in the progress of insulin secretion was controversial (Khoo \& Cobb 1997, Longuet et al. 2005), ERK1/2 was activated by insulinotropic agents. Interestingly, sulfonylureas and FSK activated ERK1/2 phosphorylation independently from glucose (Khoo \& Cobb 1997, Arnette et al. 2003), which was different from the cases for GLP1 and its analogs in glucose-dependently stimulating ERK1/2 phosphorylation. In our current work, BBT-potentiated GSIS and the glucose-induced ERK1/2 phosphorylation, demonstrating the importance of glucose concentration for BBT function. Therefore, our results further indicated that BBT may get rid of the hypoglycemic effect under normal conditions, which is a serious clinical side effect for many insulinotrophic drugs with glucose-independent stimulatory effects on insulin secretion (de Heer \& Holst 2007).

cAMP/PKA and intracellular $\mathrm{Ca}^{2+}$ have both been reported to mediate ERK1/2 phosphorylation and GSIS in $\beta$-cells (Wang et al. 1993, Briaud et al. 2003), and enhancement

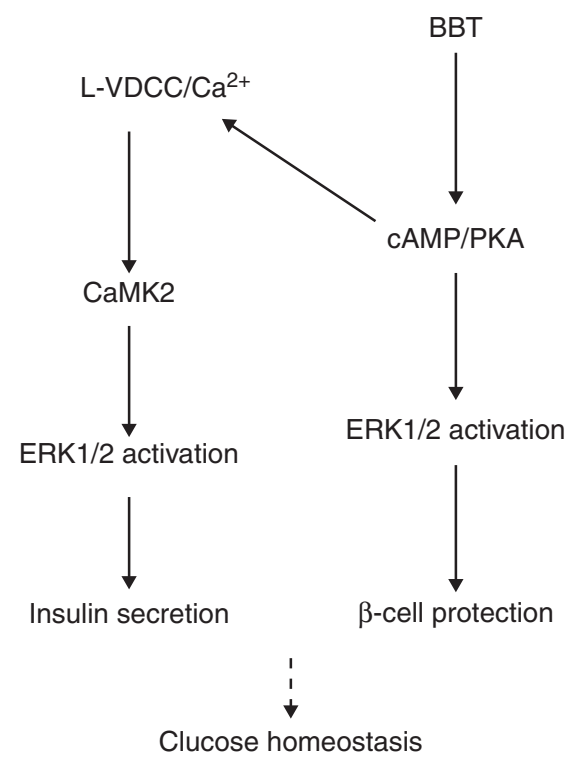

Figure 8

A proposed model interpreting the effect of BBT on $\beta$-cells. of cytoplasmic $\mathrm{Ca}^{2+}$ led to cAMP production and subsequent PKA activation (Briaud et al. 2003), while elevation of cAMP level also regulated the entry of $\mathrm{Ca}^{2+}$ into $\beta$-cells through L-VDCC to induce insulin secretion (Wang et al. 1993). GLP1 activated ERK1/2 and GSIS through activation of PKA and CaMK2 (Gomez et al. 2002). Herein, BBT enhanced the intracellular cAMP level, and then induced $\mathrm{Ca}^{2+}$ influx through L-VDCC and CaMK2 activation, and finally promoted ERK1/2 phosphorylation and insulin secretion (Fig. 8).

In pancreatic $\beta$-cells, cAMP/PKA activation has been reported to reduce apoptosis and stimulate cell survival (Hui et al. 2003), and the finding that BBT protected $\beta$-cells through activation of cAMP/PKA was consistent with the published result. Notably, the role of CaMK2 in $\beta$-cell protection was not clear, our results indicated that CaMK2 was not involved in the BBT-mediated $\beta$-cell protection although CaMK2 was activated by BBT. Furthermore, the finding that BBT could reverse the STZ- or cytokine-induced insulin secretion deficiency indicated that BBT may have potential in improving insulin secretory deficiency (Leahy et al. 1992).

As has been reported, thiophenecarboxamide-type compounds have effects on many pharmacological events, such as anti-inflammation (Baxter et al. 2004), cell cycle regulation (Janetka et al. 2008), antifungal actions, DNA damage inhibition (Shinkwin et al. 1999), and inhibition of $\mathrm{Ca}^{2+}$-release-activated calcium channels (Yonetoku et al. 2006), and no reports have been published on their anti-diabetic effects. Therefore, our current report that the thiophenecarboxamide derivative BBT efficiently improved $\beta$-cell dysfunction is expected to have expanded the pharmacological understanding of thiophenecarboxamide compounds.

In conclusion, the small-molecule thiophenecarboxamide derivative BBT was discovered to potentiate GSIS, protect $\beta$-cells, and effectively improve glucose homeostasis in type 2 diabetic mice. Both cAMP/PKA/CaMK2 and ERK1/2 pathways were involved in the BBT-promoted GSIS, and the cAMP/PKA pathway was essential for the protective effect of BBT on $\beta$-cells. Our current work has highlighted the potential of BBT in anti-hyperglycemia research.

Declaration of interest

The authors declare that there is no conflict of interest that could be perceived as prejudicing the impartiality of the research reported.

\section{Funding}

This work was supported by the National Natural Science Foundation of China (grant numbers 81373461, 81473141, 91413102, 81220108025, and 91213306).

Published by Bioscientifica Ltd 


\section{References}

Ahren B 2008 Emerging dipeptidyl peptidase-4 inhibitors for the treatment of diabetes. Expert Opinion on Emerging Drugs 13 593-607. (doi:10.1517/ $14728210802584126)$

Andersson AK, Flodstrom M \& Sandler S 2001 Cytokine-induced inhibition of insulin release from mouse pancreatic $\beta$-cells deficient in inducible nitric oxide synthase. Biochemical and Biophysical Research Communications 281 396-403. (doi:10.1006/bbrc.2001.4361)

Arnette D, Gibson TB, Lawrence MC, January B, Khoo S, McGlynn K, Vanderbilt CA \& Cobb MH 2003 Regulation of ERK1 and ERK2 by glucose and peptide hormones in pancreatic $\beta$ cells. Journal of Biological Chemistry 278 32517-32525. (doi:10.1074/jbc.M301174200)

Arulmozhi DK, Kurian R, Bodhankar SL \& Veeranjaneyulu A 2008 Metabolic effects of various antidiabetic and hypolipidaemic agents on a high-fat diet and multiple low-dose streptozocin (MLDS) mouse model of diabetes. Journal of Pharmacy and Pharmacology 60 1167-1173. (doi:10.1211/jpp.60.9.0008)

Baxter A, Brough S, Cooper A, Floettmann E, Foster S, Harding C, Kettle J, McInally T, Martin C, Mobbs M et al. 2004 Hit-to-lead studies: the discovery of potent, orally active, thiophenecarboxamide IKK-2 inhibitors. Bioorganic \& Medicinal Chemistry Letters 14 2817-2822. (doi:10.1016/j.bmcl.2004.03.058)

Benes C, Poitout V, Marie JC, Martin-Perez J, Roisin MP \& Fagard R 1999 Mode of regulation of the extracellular signal-regulated kinases in the pancreatic $\beta$-cell line MIN6 and their implication in the regulation of insulin gene transcription. Biochemical Journal 340 219-225. (doi:10.1042/0264-6021:3400219)

Briaud I, Lingohr MK, Dickson LM, Wrede CE \& Rhodes CJ 2003 Differential activation mechanisms of Erk- $1 / 2$ and $\mathrm{p} 70^{\mathrm{S} 6 \mathrm{~K}}$ by glucose in pancreatic $\beta$-cells. Diabetes 52 974-983. (doi:10.2337/diabetes.52. 4.974)

Brownlee M 2005 The pathobiology of diabetic complications: a unifying mechanism. Diabetes 54 1615-1625. (doi:10.2337/diabetes. 54.6.1615)

Butler AE, Janson J, Bonner-Weir S, Ritzel R, Rizza RA \& Butler PC 2003 $\beta$-cell deficit and increased $\beta$-cell apoptosis in humans with type 2 diabetes. Diabetes 52 102-110. (doi:10.2337/diabetes.52.1.102)

Chia CW \& Egan JM 2008 Incretin-based therapies in type 2 diabetes mellitus. Journal of Clinical Endocrinology and Metabolism 93 3703-3716. (doi:10.1210/jc.2007-2109)

Chijiwa T, Mishima A, Hagiwara M, Sano M, Hayashi K, Inoue T, Naito K, Toshioka T \& Hidaka H 1990 Inhibition of forskolin-induced neurite outgrowth and protein-phosphorylation by a newly synthesized selective inhibitor of cyclic AMP-dependent protein kinase, $\mathrm{N}$-[2-(p-bromocinnamylamino)ethyl]-5-isoquinolinesulfonamide (H-89), of Pc12d pheochromocytoma cells. Journal of Biological Chemistry 265 $5267-5272$.

Cognard E, Dargaville CG, Hay DL \& Shepherd PR 2013 Identification of a pathway by which glucose regulates $\beta$-catenin signalling via the cAMP/protein kinase A pathway in $\beta$-cell models. Biochemical Journal 449 803-811. (doi:10.1042/BJ20121454)

Delaney CA, Dunger A, DiMatteo M, Cunningham JM, Green MH \& Green IC 1995 Comparison of inhibition of glucose-stimulated insulin secretion in rat islets of Langerhans by streptozotocin and methyl and ethyl nitrosoureas and methanesulphonates. Biochemical Pharmacology 50 2015-2020. (doi:10.1016/0006-2952(95)02102-7)

Doupis J \& Veves A 2008 DPP4 inhibitors: a new approach in diabetes treatment. Advances in Therapy 25 627-643. (doi:10.1007/s12325008-0076-1)

Duncia JV, Santella JB, Higley CA, Pitts WJ, Wityak J, Frietze WE, Rankin FW, Sun JH, Earl RA, Tabaka AC et al. 1998 MEK inhibitors: the chemistry and biological activity of U0126, its analogs, and cyclization products. Bioorganic \& Medicinal Chemistry Letters 8 2839-2844. (doi:10.1016/S0960-894X(98)00522-8)
Easom RA 1999 CaM kinase II: a protein kinase with extraordinary talents germane to insulin exocytosis. Diabetes 48 675-684. (doi:10.2337/ diabetes.48.4.675)

Gastaldelli A 2011 Role of $\beta$-cell dysfunction, ectopic fat accumulation and insulin resistance in the pathogenesis of type 2 diabetes mellitus. Diabetes Research and Clinical Practice 93 S60-S65. (doi:10.1016/ S0168-8227(11)70015-8)

Girgis CM \& Champion BL 2011 Vildagliptin-induced acute pancreatitis. Endocrine Practice 17 e48-e50. (doi:10.4158/EP10383.CR)

Gomez E, Pritchard C \& Herbert TP 2002 cAMP-dependent protein kinase and $\mathrm{Ca}^{2+}$ influx through L-type voltage-gated calcium channels mediate Raf-independent activation of extracellular regulated kinase in response to glucagon-like peptide-1 in pancreatic $\beta$-cells. Journal of Biological Chemistry 277 48146-48151. (doi:10.1074/jbc.M209165200)

Han SJ, Kang ES, Hur KY, Kim HJ, Kim SH, Yun CO, Choi SE, Ahn CW, Cha BS, Kang Y et al. 2008 Rosiglitazone inhibits early stage of glucolipotoxicity-induced $\beta$-cell apoptosis. Hormone Research 70 165-173. (doi:10.1159/000137662)

de Heer J \& Holst JJ 2007 Sulfonylurea compounds uncouple the glucose dependence of the insulinotropic effect of glucagon-like peptide 1. Diabetes 56 438-443. (doi:10.2337/db06-0738)

Hohmeier HE, Mulder H, Chen GX, Henkel-Rieger R, Prentki M \& Newgard CB 2000 Isolation of INS-1-derived cell lines with robust ATP-sensitive $\mathrm{K}^{+}$channel-dependent and -independent glucosestimulated insulin secretion. Diabetes 49 424-430. (doi:10.2337/ diabetes.49.3.424)

Hui HX, Nourparvar A, Zhao XN \& Perfetti R 2003 Glucagon-like peptide-1 inhibits apoptosis of insulin-secreting cells via a cyclic $5^{\prime}$-adenosine monophosphate-dependent protein kinase A- and a phosphatidylinositol 3-kinase-dependent pathway. Endocrinology 144 1444-1455. (doi:10.1210/en.2002-220897)

Janetka JW, Almeida L, Ashwell S, Brassil PJ, Daly K, Deng C, Gero T, Glynn RE, Horn CL, Ioannidis S et al. 2008 Discovery of a novel class of 2-ureido thiophene carboxamide checkpoint kinase inhibitors. Bioorganic \& Medicinal Chemistry Letters 18 4242-4248. (doi:10.1016/ j.bmcl.2008.05.016)

Kaihara KA, Dickson LM, Jacobson DA, Tamarina N, Roe MW, Philipson LH $\&$ Wicksteed B $2013 \beta$-cell-specific protein kinase A activation enhances the efficiency of glucose control by increasing acute-phase insulin secretion. Diabetes 62 1527-1536. (doi:10.2337/db12-1013)

Kajimoto Y \& Kaneto H 2004 Role of oxidative stress in pancreatic $\beta$-cell dysfunction. Annals of the New York Academy of Sciences 1011 168-176. (doi:10.1196/annals.1293.017)

Khoo S \& Cobb MH 1997 Activation of mitogen-activating protein kinase by glucose is not required for insulin secretion. PNAS $\mathbf{9 4} 5599-5604$. (doi:10.1073/pnas.94.11.5599)

Leahy JL 1990 Natural history of $\beta$-cell dysfunction in NIDDM. Diabetes Care 13 992-1010. (doi:10.2337/diacare.13.9.992)

Leahy JL, Bonnerweir S \& Weir GC $1992 \beta$-cell dysfunction induced by chronic hyperglycemia - current ideas on mechanism of impaired glucose-induced insulin secretion. Diabetes Care 15 442-455. (doi:10.2337/diacare.15.3.442)

Li L, El-Kholy W, Rhodes CJ \& Brubaker PL 2005 Glucagon-like peptide-1 protects beta cells from cytokine-induced apoptosis and necrosis: role of protein kinase B. Diabetologia 48 1339-1349. (doi:10.1007/s00125005-1787-2)

Longuet C, Broca C, Costes S, Hani E, Bataille D \& Dalle S 2005 Extracellularly regulated kinases $1 / 2$ (p44/42 mitogen-activated protein kinases) phosphorylate synapsin I and regulate insulin secretion in the MIN6 $\beta$-cell line and islets of Langerhans. Endocrinology 146 643-654. (doi:10.1210/en.2004-0841)

Lytton J, Westlin M \& Hanley MR 1991 Thapsigargin inhibits the sarcoplasmic or endoplasmic reticulum Ca-ATPase family of calcium pumps. Journal of Biological Chemistry 266 17067-17071.

Maedler K, Sergeev P, Ris F, Oberholzer J, Joller-Jemelka HI, Spinas GA, Kaiser N, Halban PA \& Donath MY 2002 Glucose-induced $\beta$ cell production of 
IL-1 $\beta$ contributes to glucotoxicity in human pancreatic islets. Journal of Clinical Investigation 110 851-860. (doi:10.1172/JCI200215318)

Meece J 2007 Pancreatic islet dysfunction in type 2 diabetes: a rational target for incretin-based therapies. Current Medical Research and Opinion 23 933-944. (doi:10.1185/030079906X167336)

Prentki M \& Nolan CJ 2006 Islet $\beta$ cell failure in type 2 diabetes. Journal of Clinical Investigation 116 1802-1812. (doi:10.1172/JCI29103)

Quevedo J, Vianna M, Daroit D, Born AG, Kuyven CR, Roesler R \& Quillfeldt JA 1998 L-type voltage-dependent calcium channel blocker nifedipine enhances memory retention when infused into the hippocampus. Neurobiology of Learning and Memory 69 320-325. (doi:10.1006/nlme.1998.3822)

Rachdi L, Kariyawasam D, Guez F, Aiello V, Arbones ML, Janel N, Delabar JM, Polak M \& Scharfmann R 2014 Dyrk1a haploinsufficiency induces diabetes in mice through decreased pancreatic beta cell mass. Diabetologia 57 960-969. (doi:10.1007/s00125-014-3174-3)

Renstrom E, Eliasson L \& Rorsman P 1997 Protein kinase A-dependent and -independent stimulation of exocytosis by cAMP in mouse pancreatic B-cells. Journal of Physiology 502 105-118. (doi:10.1111/j.1469-7793. 1997.105bl.x)

Rhodes CJ 2005 Type 2 diabetes - a matter of $\beta$-cell life and death? Science 307 380-384. (doi:10.1126/science.1104345)

Ritzel RA, Hansen JB, Veldhuis JD \& Butler PC 2004 Induction of $\beta$-cell rest by a Kir6.2/SUR1-selective K-ATP-channel opener preserves $\beta$-cell insulin stores and insulin secretion in human islets cultured at high $(11 \mathrm{mM})$ glucose. Journal of Clinical Endocrinology and Metabolism 89 795-805. (doi:10.1210/jc.2003-031120)

Rustenbeck I, Herrmann C \& Grimmsmann T 1997 Energetic requirement of insulin secretion distal to calcium influx. Diabetes 46 1305-1311. (doi:10.2337/diab.46.8.1305)

Seifert R, Lushington GH, Mou TC, Gille A \& Sprang SR 2012 Inhibitors of membranous adenylyl cyclases. Trends in Pharmacological Sciences $\mathbf{3 3}$ 64-78. (doi:10.1016/j.tips.2011.10.006)

Seino Y, Rasmussen MF, Nishida T \& Kaku K 2010 Efficacy and safety of the once-daily human GLP-1 analogue, liraglutide, vs glibenclamide monotherapy in Japanese patients with type 2 diabetes. Current Medical Research and Opinion 26 1013-1022. (doi:10.1185/03007991003672551)

Seino S, Shibasaki T \& Minami K 2011 Dynamics of insulin secretion and the clinical implications for obesity and diabetes. Journal of Clinical Investigation 121 2118-2125. (doi:10.1172/JCI45680)

Shibasaki T, Sunaga Y \& Seino S 2004 Integration of ATP, cAMP, and $\mathrm{Ca}^{2+}$ signals in insulin granule exocytosis. Diabetes 53 S59-S62. (doi:10.2337/diabetes.53.suppl_3.S59)

Shinkwin AE, Whish WJ \& Threadgill MD 1999 Synthesis of thiophenecarboxamides, thieno $[3,4-c]$ pyridin-4(5H)-ones and thieno[3,4- $d]$ pyrimidin-4(3H)-ones and preliminary evaluation as inhibitors of poly(ADP-ribose)polymerase (PARP). Bioorganic \& Medicinal Chemistry 7 297-308. (doi:10.1016/S0968-0896(98)00210-7)

Stephan D, Winkler M, Kuhner P, Russ U \& Quast U 2006 Selectivity of repaglinide and glibenclamide for the pancreatic over the cardiovascular K-ATP channels. Diabetologia 49 2039-2048. (doi:10.1007/ s00125-006-0307-3)

Sumi M, Kiuchi K, Ishikawa T, Ishii A, Hagiwara M, Nagatsu T \& Hidaka H 1991 The newly synthesized selective $\mathrm{Ca}^{2+}$ /calmodulin dependent protein kinase II inhibitor KN-93 reduces dopamine contents in Pc12h cells. Biochemical and Biophysical Research Communications 181 968-975. (doi:10.1016/0006-291X(91)92031-E)

Suzuki M, Fujikura K, Kotake K, Inagaki N, Seino S \& Takata K 1999 Immuno-localization of sulphonylurea receptor 1 in rat pancreas. Diabetologia 42 1204-1211. (doi:10.1007/s001250051293)
Szkudelski T 2001 The mechanism of alloxan and streptozotocin action in B cells of the rat pancreas. Physiological Research 50 537-546.

Tokumitsu H, Inuzuka H, Ishikawa Y \& Kobayashi R 2003 A single amino acid difference between $\alpha$ and $\beta \mathrm{Ca}^{2+} /$ calmodulin-dependent protein kinase kinase dictates sensitivity to the specific inhibitor, STO-609. Journal of Biological Chemistry 278 10908-10913. (doi:10.1074/jbc. M213183200)

Volmat V \& Pouyssegur J 2001 Spatiotemporal regulation of the p42/p44 MAPK pathway. Biology of the Cell 93 71-79. (doi:10.1016/S02484900(01)01129-7)

Wang JL, Corbett JA, Marshall CA \& McDaniel ML 1993 Glucose-induced insulin secretion from purified $\beta$-cells. A role for modulation of $\mathrm{Ca}^{2+}$ influx by cAMP- and protein kinase C-dependent signal transduction pathways. Journal of Biological Chemistry 268 7785-7791.

Wang T, Zhou GY, Ma J, Zhao YY, Feng ZY, Tang XQ \& Ling WH 2000 Study on non insulin-dependent diabetes mellitus model in C57BL/6J mice induced by streptozotocin. Acta Laboratorium Animalis Scientia Sinica $\mathbf{8}$ 92-97. (doi:10.3969/j.issn.1005-4847.2000.02.006)

Webster CR \& Anwer MS 1998 Cyclic adenosine monophosphate-mediated protection against bile acid-induced apoptosis in cultured rat hepatocytes. Hepatology 27 1324-1331. (doi:10.1002/hep.510270519)

Wijesekara N, Krishnamurthy M, Bhattacharjee A, Suhail A, Sweeney G \& Wheeler MB 2010 Adiponectin-induced ERK and Akt phosphorylation protects against pancreatic beta cell apoptosis and increases insulin gene expression and secretion. Journal of Biological Chemistry 285 33623-33631. (doi:10.1074/jbc.M109.085084)

Wrede CE, Dickson LM, Lingohr MK, Briaud I \& Rhodes CJ 2002 Protein kinase $\mathrm{B} / \mathrm{Akt}$ prevents fatty acid-induced apoptosis in pancreatic $\beta$-cells (INS-1). Journal of Biological Chemistry 277 49676-49684. (doi:10.1074/ jbc.M208756200)

Wu Y, Ouyang JP, Wu K, Wang SS, Wen CY \& Xia ZY 2005 Rosiglitazone ameliorates abnormal expression and activity of protein tyrosine phosphatase $1 \mathrm{~B}$ in the skeletal muscle of fat-fed, streptozotocin-treated diabetic rats. British Journal of Pharmacology 146 234-243. (doi:10.1038/ sj.bjp.0706306)

Xia ZG, Dickens M, Raingeaud J, Davis RJ \& Greenberg ME 1995 Opposing effects of ERK and JNK-p38 MAP kinases on apoptosis. Science 270 1326-1331. (doi:10.1126/science.270.5240.1326)

Yao XG, Chen FL, Li P, Quan LL, Chen J, Yu L, Ding H, Li CJ, Chen LL, Gao ZB et al. 2013 Natural product vindoline stimulates insulin secretion and efficiently ameliorates glucose homeostasis in diabetic murine models. Journal of Ethnopharmacology 150 285-297. (doi:10.1016/j.jep.2013.08.043)

Yeo RW, Yang KY, Li GD \& Lim SK 2012 High glucose predisposes gene expression and ERK phosphorylation to apoptosis and impaired glucose-stimulated insulin secretion via the cytoskeleton. PLOS ONE 7 e44988. (doi:10.1371/journal.pone.0044988)

Yokota T, Ma RC, Park JY, Isshiki K, Sotiropoulos KB, Rauniyar RK, Bornfeldt KE \& King GL 2003 Role of protein kinase C on the expression of platelet-derived growth factor and endothelin-1 in the retina of diabetic rats and cultured retinal capillary pericytes. Diabetes $\mathbf{5 2}$ 838-845. (doi:10.2337/diabetes.52.3.838)

Yonetoku Y, Kubota H, Okamoto Y, Toyoshima A, Funatsu M, Ishikawa J, Takeuchi M, Ohta M \& Tsukamoto S 2006 Novel potent and selective calcium-release-activated calcium (CRAC) channel inhibitors. Part 1: synthesis and inhibitory activity of 5-(1-methyl-3-trifluoromethyl$1 H$-pyrazol-5-yl)-2-thiophenecarboxamides. Bioorganic \& Medicinal Chemistry 14 4750-4760. (doi:10.1016/j.bmc.2006.03.024)

Zimmet P, Alberti KG \& Shaw J 2001 Global and societal implications of the diabetes epidemic. Nature $\mathbf{4 1 4}$ 782-787. (doi:10.1038/414782a)

Received in final form 24 December 2014

Accepted 8 January 2015

Accepted Preprint published online 8 January 2015 http://joe.endocrinology-journals.org DOI: 10.1530/JOE-14-0721
Cㄱ 2015 Society for Endocrinology Printed in Great Britain 